\title{
TANTANGAN ORGANISASI BUNDO KANDUANG DALAM MENDORONG REPRESENTASI PEREMPUAN DI LEMBAGA LEGISLATIF SUMATERA BARAT
}

\author{
Soraya Oktarina \\ Mahasiswa Pascasarjana Universitas Indonesia \\ Email: sorayaoktarin4@gmail.com
}

\begin{abstract}
Abstrak
Tesis ini membahas tentang peran dan tantangan yang di hadapi Organisasi Bundo Kanduang Dalam Mendorong Representasi Perempuandi Lembaga Legislatif Sumatera Barat. Penelitian ini adalah penilitian kualitatif dengan desain deskriptif. Hasil penelitian memaparkan bahwa adanya Undang-undang No.22 tahun 1999 yang kemudian direvisi dengan Undangundang No.32 tahun 2004 tentang Otonomi Daerah berdampak terhadap berlakunya sistem demokrasi lokal di sejumlah daerah di Indonesia, salah satunya Sumatera Barat. Provinsi Sumatera Barat merupakan daerah yang corak kebudayaanya khas, menganut asas matrilineal, perempuan menempati posisi sentral. Peran perempuan Sumatera Barat atau yang dikenal dengan istilah bundo kanduang kemudian diperkuat melalui Peraturan daerah tentang Pemerintahan Nagari. Bundo kanduang tidak hanya sebagai pelestari adat, namun juga memiliki peran politis sebagai penentu kebijakan. Organisasi Bundo Kanduang, sebagai salah satu kelompok perempuan Minangkabau berupaya mendorong kehadiran perempuan di dalam lembaga kebijakan melalui peningkatan kapasitas perempuan, mulaidaritingkatnagarihingga provinsi. Realitanya, tak sedikit hambatan yang harus dihadapi dalam menghadirkan perempuan di dalam pengambil kebijakan. Kentalnya akulturasi budaya patriarkhi, doktrin Agama, hingga adanya dualisme sistem pemerintahan yang berjalan di Sumatera Barat menjadi isu utama. Tak hayal, peran organisasi bundo kanduang pun hanya mampu berjalan di tataran subtantif seremonial.
\end{abstract}

kata kunci : Bundo Kanduang, Organisasi Bundo Kanduang 


\section{TANTANGAN ORGANISASI BUNDO KANDUANG DALAM MENDORONG REPRESENTASI PEREMPUAN DI LEMBAGA LEGISLATIF SUMATERA BARAT}

\section{Pendahuluan.}

Momentum otonomi daerah yang dinyatakan dalam Undang-undang No.22 tahun 1999 yang kemudian telah mengalami dua kali revisi, yakni Undang-undang No. 32 tahun 2004 dan Undang-undang No. 23 tahun 2014 menjadi sebuah kesempatan strategis untuk mewujudkan kembali berlakunya sistem demokrasi lokal di sejumlah daerah di Indonesia, salah satunya Sumatera Barat, yang setelah sekian lama "tercabut" akibat pemberlakuan Undang-undang No.5 tahun 1979 tentang pemerintahan desa dan telah menyebabkan pemisahan secara tajam terhadap unsur adat dan unsur administrasi pemerintahan pada masa sistem politik Orde Baru. Sebagai upaya menghidupkan kembali identitas kultural lokal, Provinsi Sumatera Barat memberlakukan sistem pemerintahan nagari yang kemudian disahkan dalam bentuk Peraturan Daerah No. 9 Tahun 2000 tentang Pemerintahan Nagari dan diperbaharui dengan Peraturan Daerah Sumatera Barat No. 2 tahun 2007 tentang Pokok-pokok Peraturan Nagari.

Pemerintahan nagari merupakan pemerintahan terendah setingkat desa yang berada di wilayah Provinsi Sumatera Barat. Perda nagari adalah suatu landasan hukum yang mengatur secara penuh unsur-unsur pendukung kehidupan politik di nagari, termasuk juga mengatur tentang keterlibatan dari institusi-institusi adat lokal yang ada di nagari, pembentukan lembagalembaga pemerintahan formal di nagari, yang bertujuan untuk membangun lagi citra pemerintahan nagari yang sesuai dengan rumusan Adat Basandi Syarak, Syarak Basandi Kitabullah. Dalam konsep Adat Basandi Syarak, Syarak Basandi Kitabullah, penyelenggaraan 
pemerintahan nagari secara prosedural berada pada konteks demokrasi lokal yang bersumber pada kearifan lokal masyarakat nagari dengan keterlibatan unsur-unsur lokalitas adat.

Pada pasal 5 Perda Nagari tahun 2000 dan pada pasal 12 Perda Nagari tahun 2007 ikut mensyaratkan masuknya semua elemen masyarakat lokal dalam setiap pengambilan keputusan publik. Adapun elemen-elemen masyarakat lokal tersebut meliputi unsur ninik mamak, alim ulama, cadiak pandai, bundo kanduang dan pemuda. Di dalam Peraturan Daerah No.9 tahun 2000 tentang Pemerintahan Nagari memuat bahwa pemerintahan nagari terdiri dari pemerintah nagari sebagai eksekutif dan Badan Perwakilan Anak Nagari (BPAN) sebagai legislatif, yang mana pada pasal 5 perda ini menjelaskan bahwa BPAN sebagai lembaga legislatif mensyaratkan masuknya bundo kanduang sebagai elemen penting dari perwakilan masyarakat. Sementara pada Perda No.2 tahun 2007 tentang Pokok-Pokok Pemerintahan Nagari, pada pasal 12 ayat 1 secara gamblang disebutkan "bahwa anggota Badan Musyawarah Nagari (BAMUS) terdiri dari unsur ninik mamak/tokoh adat/ kepala suku, alim ulama/tokoh agama, cadiak pandai/cendikiawan, bundo kanduang/ tokoh perempuan dan komponen masyarakat lainnya yang tumbuh dan berkembang dalam nagari bersangkutan dengan mempertimbangkan representasi daerah yang ditetapkan dengan cara musyawarah dan mufakat.

Keberadaan perda nagari dan didukung adanya perubahan struktur sistem pemerintahan lokal Sumatera Barat, turut menyebabkan pula perubahan pada representasi dan peran pada lembaga-lembaga adat, salah satu bundo kanduang. Jika dahulu keberadaan bundo kanduang hanya diartikan berada dalam tataran individu atau personal, maka paska adanya perubahan dinamika politik lokal, bundo kanduang mulai diakui menjadi sebuah institusi yang khusus merepresentasikan kaum perempuan dan berperan dalam mempengaruhi kebijakan peremerintah. Tak hanya itu, terbukanya regulasi lokal bagi peran politik bundo kanduang ini juga menjadi 
sebuah kesempatan strategis dalam menghadirkan wakil-wakil perempuan di lembaga legislatif Sumatera Barat mulai dari nagari hingga Provinsi.

Realita sosial politik Sumatera Barat saat ini, angka keberadaaan perempuan dalam lembaga legislatif dan pengambil keputusan masih minim baik mulai dari tingat nagari, Kabupaten/Kota hingga Provinsi. Keterwakilan perempuan di Badan Musyawarah Nagari seSumatera Barat saat ini hanya mencapai angka 9 persen. Rendahnya keterwakilan perempuan di lembaga legislatif juga terefleksikan dalam lembaga politik formal di tingkat Kabupaten/ Kota maupun Provinsi. Kehadiran perempuan di lembaga legislatif se Sumatera Barat tak mampu mencapai syarat kuota 30 persen. Presentasi jumah keterwakilan perempuan di lembaga legislatif Provinsi Sumatera Barat hanya mencapai 9,2 \%, dan di Kabupaten/Kota sebesar 7,2 \%. Dari 18 Kabupaten/kota yang terdapat di Provinsi Sumatera Barat, bahkan masih terdapat dua daerah yang sama sekali tidak memiliki wakil perempuan yakni Kabupaten Solok Selatan dan Kabupaten Kepulauan Mentawai.

Meskipun menganut budaya matrilineal dan peran politik perempuan telah dilegalisasi kedalam perda, namun kenyataan menunjukan perempuan-perempuan di Sumatera Barat belum dapat mengisi kursi legislatif secara maksimal, bahkan kehadiran perempuan di lembaga pembuat kebijakan tersebut terus mengalami penurunan. Ketiadaan wakil perempuan di lembaga pembuat kebijakan tentu akan berdampak kepada minimnya output kebijakan-kebijakan yang ramah perepuan. Untuk itu perlu diupayakan strategi peningkatan keterwakilan perempuan Sumatera Barat dari berbagai saluran lainnya, salah satunya melalui kekuatan dan keaktifan institusi-intitusi lokal adat

Seperti yang di ungkapkan Manon Tremblay, sistem pemilu, termasuk di dalamnya kuota perempuan dan partai politik memiliki potensi untuk memengaruhi proporsi perempuan dalam 
parlemen. Namun sistem pemilu tidak berdiri sendiri dalam memengaruhi proporsi perempuan tersebut. Ia harus berinteraksi dengan faktor budaya, sosio-ekonomi dan politik secara dinamis untuk dapat memengaruhi proporsi perempuan dalam parlemen. Faktor budaya menurut Trembley merujuk pada nilai, norma, kepercayaan dan prilaku yang menyokong suatu masyarakat beserta institusinya dan menjadi sandaran dari seluruh aspek kehidupan masyarakat tersebut. Sri Zulchairiyah menggunakan istilah Vote Getter atau pengumpul suara untuk mendapatkan dukungan pemilih di Sumatera Barat. Merujuk pada yang disampaikan Tremblay, menggunakan institusi budaya kemudian menjadi penting dalam mendulang suara bagi caleg perempuan, dimana vote gette yang paling memiliki pengaruh yani tokoh-tokoh masyarakat perempuan yakni institusi Bundo Kandung.

Meski dahulunya organisasi bundo kanduang hadir sebagai alat kepentingan politik penguasa Orde Baru, namun paska Orba runtuh, semangat reformasi dan transformasi pun hadir pada institusi bundo kanduang, baik secara personal ataupun organisasi . Organisasi bundo kanduang kemudian tumbuh menjadi sebuah infrastruktur politik yang dapat mempengaruhi kehidupan sistem politik di Sumatera Barat. Organisasi bundo kanduang bertindak sebagai mitra pemerintah lokal Sumatera Barat dalam mengawasi jalannya pemerintahan, melakukan berbagai konsolidasi dengan aparat pemerintahan serta masyarakat, terutama yang terkait dengan peningkatan pada program pemberdayaan kaum perempuan. Organisasi bundo kanduang kemudian hadir sebagai sebuah gerakan sosial politik untuk mengembalikan peran sentral kaum perempuan Sumatera Barat sesuai dengan prinsip matrilineal. Hal ini sesuai dengan visi yang dituangkan dalam pasal 7 Anggaran Dasar dan Anggaran Rumah tangga Organisasi bundo kanduang tahun 2015 - 2020 yakni terwujudnya kedudukan, peranan dan fungsi perempuan serta generasi muda minangkabau sesuai dengan tatanan adat minangkabau. 
Sebagai sebuah kelompok perempuan yang diakui keberadaannya, organisasi bundo kanduang menjadi salah satu modal sosial yang sangat strategis dalam memperjuangkan hak-hak kaum perempuan, termasuk dalam hal meningkatkan angka keterwakilan perempuan di lembaga pembuat kebijakan Sumatera Barat, mulai dari tingkat nagari hingga Provinsi. Menghadirkan perempuan di wilayah publik khususnya dalam lembaga pengambilan keputusan, perlu diupayakan dengan menghidupkan kembali power dan bargainning position perempuan mulai dari ruang lingkup nagari sebagai kelompok wilayah terkecil dalam sistem pemerintahan Sumatera Barat.

Namun dalam perjalanannya, tak sedikit hambatan dan tantangan yang harus dihadapi lembaga bundo kanduang dalam memperjuangkan aspirasi perempuan di Sumatera Barat, terlebih dalam hal mendorong keberadaan wakil perempuan di lembaga pengambil kebijakan. Berbagai macam faktor-faktor tantangan terus "menghantam" organisasi bundo kanduang dalam mendorong keberadaan perempuan dalam pengambil keputusan baik berasal dari tubuh organisasi bundo kanduang itu sendiri, berasal dari faktor ekstern seperti budaya dan agama, keberadaan isu kebijakan, serta adanya otonomi atau kebebasan yang diberikan kepada organisasi bundo kanduang. Sejumlah hambatan inilah yang menyebabkan upaya organisasi bundo kanduang dalam mengembalikan peran sentral perempuan minangabau kian berada dalam posisi dilematis dan berat. Berdasarkan fenomena tersebut, penulis tertarik untuk meneliti lebih lanjut tentang "Tantangan Organisasi Bundo kanduang Dalam Mendorong Representasi Perempuan Di Lembaga Legislatif Sumatera Barat" . 


\section{Tinjauan Pustaka}

\section{A. Modal Sosial}

Untuk mampu bersaing dalam ajang pemilihan umum, seorang aleg perempuan harus memiliki kekuatan-kekuatan modal yang menjadi power ketika bertarung dengan caleg lainnya. Setidaknya terdapat 3 (tiga) modal utama yang menentukan daya saing seorang calon legislatif di dalam pemilihan umum, yakni; modal politik, modal ekonomi dan modal sosial. Modal politik yang dimiliki oleh perempuan Sumatera Barat jelas memiliki perbedaan dengan laki-laki ketika perempuan saat ini masih termarjinal di dalam partai. Modal politik adalah kecakapan pengetahuan, pengalaman dan pemahaman yang berhubungan dengan politik dan sistem pemilihan. Seorang caleg harus mengetahui mulai dari sistem tata cara pemilihan, strategi, dan potensi potensi kemenangan peta politiknya dimulai dari internal partai. Modal ekonomi atau keuangan (pendanaan) yangjuga mempunyaikontribusi yang signifikan bagi keberhasilan pencalegan. Sumberpendanaan bagi calon legislatif yang akan bertarung di pemilihan umum digunakan untuk menemui konstituen, pembuatanatribut, aktivitas politik untuk kegiatan pemenangan dan pengawasan pemilu. Keterbatasan modal politik dan modal ekonomi kemudian bisa diatasi dengan keberadaan modal yang ketiga, yakni modal sosial

Terdapat banyak definisi ahli mengenai modal sosial. Robert D. Putnam, mendefinisikan modal sosial sebagai sesuatu karakteristik yang ada di dalam organisasi sosial, semisal kepercayaan, norma, dan jejaring yang bisa memperbaiki efisiensi masyarakat melalui memfasilitasi aksi-aksi yang terkoordinasikan (John Field : 2008). Modal sosial menjembatani masyarakat dalam kerjasama dan mengurangi perpecahan sosial. Keanggotaan jaringan dan 
seperangkat nilai bersama menjadi inti dari konsep modal sosial. Modal sosial mengacu pada hubungan sosial dengan kehadiran norma dan kepercayaan.

Kemudian Lang \& Hornburg (1998) berpendapat bahwa modal sosial umumnya merujuk pada ketersediaan rasa saling percaya di dalam masyarakat (stocks of sosial trust), norma-norma, dan jejaring yang dapat dimanfaatkan masyarakat dalam rangka menyelesaikan persoalanpersoalan bersama. Sementara itu, Fukuyama (2000: 3) mengatakan tentang modal sosial, yakni modal sosial sebagai norma informal yang mendorong terjadinya kerjasama diantara dua orang atau lebih. Norma yang mengatur modal sosial bisa berasal dari norma resiprositas (hubungan timbalbalik) diantara dua teman. Norma-norma yang demikian harus diwujudkan dalam hubungan antar manusia secara nyata: norma hubungan timbal-balik selalu ada dan potensial untuk bisa diwujudkan dalam hubungan dengan semua orang. Terdapat konsepsi spesifik tentang modal sosial yakni : (1) sekumpulan sumberdaya aktual dan potensial; (2) entitasnya terdiri-dari atas beberapa aspek dari struktur sosial, dan entitas-entitas tersebut memfasilitasi tindakan individu-individu yang ada dalam struktur tersebut; (3) asosiasi-asosiasi yang bersifat horisontal; (3) kemampuan aktor untuk menjamin manfaat; (4) informasi; (5) norma-norma; (6) nilai-nilai; (7) resiprositas; (8) kerjasama; (9) jejaring.

Perbedaan mendasar modal sosial dari modal-modal lainnya, adalah bahwa modal sosial bukanlah milik individu, tetapi muncul sebagai hasil dari hubungan individu, sedangkan modalmodal lainnya dapat menjadi milik individu. Modal sosial dapat terwujud di dalam kelompok sosial yang paling kecil, seperti keluarga, tetapi dapat juga terwujud dalam kelompok sosial yang paling besar seperti negara. Modal sosial diciptakan dan ditransmisikan melalui mekanisme budaya, seperti tradisi, kebiasaan-kebiasaan..Konsep Modal Sosial digunakan dalam penelitian ini untuk melihat kedudukan dan peranan organisasi bundo kanduang dalam mendorong 
keterwakilan perempuan di lembaga legislatif di Sumatera Barat, dimana organisasi bundo kanduang dinilai sebagai salah satu modal sosial yang dimiliki oleh perempuan Sumatera Barat dalam untuk masuk dan bersaing dalam memperebutkan kembali posisi sentral perempuan sesuai dengan tatanan adat Minangkabau.

\section{b. Representasi Bundo Kanduang di Sumatera Barat}

Secara umum perempuan adalah bagian dari civil society yang merupakan unsur pokok dalam setiap perubahan baik sosial dan politik. Didalam adat, perempuan adalah institusi. Dalam tataran sistem matrilineal di Minangkabau secara normatif, kaum perempuan biasa disebut dengan bundo kanduang, yang tidak dapat dipisahkan dari aspek sosial, budaya, ekonomi, maupun politik, karena aspek tersebut telah memberikan kedudukan dan ruang tersendiri bagi perempuan minang untuk berperan dalam setiap dimensi kehidupan masyarakat.

Bundo kanduang adalah refleksi perwakilan perempuan. Sebagai perempuan Minangkabau yang diberikan kehormatan dan keutamaan menurut adat, bundo kandung juga penerima keturunan menurut ibu, penerima ketentuan rumah tempat tinggal, penerima ketentuan bahwa harta dan sumber ekonomi diutamakan untuk perempuan, penerima ketentuan untuk penyimpanan hasil usaha ekonomi, serta pemegang hak istimewa dalam bermusyawarah. Bundo kanduang dalam konteks adat, tidak hanya bertanggung jawab dalam hal pemeliharaan nilai-nilai budaya dan spiritual, tetapi juga mengontrol dan memerintah anak keturunannya (offspring). Dan karena itu konsekuensi dari peranannya tersebut membentuk kehidupan bundo kanduang dalam suatu atmosfir yang sempurna untuk memperoleh pengaruh yang besar dalam lingkungan keluarga dan untuk peran politik yang krusial dalam lingkungan publik.

Terdapat beberapa kategori bundo kanduang menurut Ketua Organisasi Bundo Kanduang yakni ; 
a.Bundo kanduang dalam mitologi.. Bundo kanduang sebagai tokoh sentral dalam kaba cindua mato, sebuah cerita rakyat yang akhirnya menjadi sebuah mitologi. Bundo kanduang dalam kaba tersebut adalah panggilan bagi raja Minangkabau yang perempuan. Hal ini dapat dilihat sebagai sebuah refleksi masyarakat tentang peranan, fungsi dan eksistensi perempuan Minangkabau.

b.Bundo kanduang dalam sejarah. Dalam sejarah kerajaan pagaruyung yang tertuang dalam tambo pagaruyung tercatat lima perempuan yang menjadi raja adat dan satu perempuan memangku ketiga gelaran yaitu Rajo Alam, Rajo Ibadat, Dan Rajo Adat (kerajaan pagaruyung memiliki Rajo Tigo Selo; Rajo Alam, Rajo Adat Dan Rajo Ibadat).

c.Bundo kanduang sebagai salah satu unsur perangkat adat. Perempuan Minangkabau berperan aktif di tengah kaumnya secara nyata. Mereka sangat mengetahui fungsi, hak dan kewajibannya sebagai perempuan di dalam keluarga atau kaumnya. Pada kondisikondisi tertentu, perempuan adat mempergunakan hak vetonya terhadap suatu keputusan kaum, terutama bila penghulu atau kepala kaum mereka tidak menjalankan fungsi dengan baik.

d.Bundo kanduang dalam realitas sosial. Bundo kanduang (atau disebut juga mande) adalah julukan bagi individu perempuan minangkabau yang sudah bekeluarga (bersuami) dan berketurunan. Perempuan Minangkabau yang belum bersuami belum dikategorikan sebagai bundo kanduang. Mereka masih berada dalam kategori "anak kemenakan". 
e.Bundo kanduang dalam konteks politik. Bundo kanduang merupakan sebuah organisasi perempuan minangkabau. Organisasi ini dapat menjalankan fungsi sosialnya sebagai kasalitator, fasilitator, motivator dan penggerak.

Keberadaan bundo kanduang tidak bisa dilepaskan sebagai salah satu unsur budaya lokal dari kultur adat Minangkabau yang berpijak pada sistem martilinealnya. Kedudukan bundo kanduang adalah kukuh, kuat dan anggun. Bundo kanduang adalah figur sentral dalam keluarga. Dia merupakan pusat jala dari keseluruhan sistem dalam keluarga. Semua persoalan dalam keluarga dinisbatkan kepadanya, dan dia adalah penentu kebijaksanaan dalam keluarga dan pengontrol kekuasaan., Bundo kanduang juga dituntut harus paham terhadap adat-istiadat didalam Nagarinya.

Dalam undang-undang adat Minangkabau, kedudukan bundo kanduang sangatlah penting dan kuat. Pertama, bundo kanduang sebagai penentu garis keturunan dan pembentukan perilaku.Kedua, bundo kanduang sebagai limpapeh rumah gadang yang berarti perempuan yang berkedudukan sebagai penguasa rumah gadang. Ketiga, perempuan pemilik harta pusaka maksudnya pemilikan harta, terutamanya tanah dan apa saja yang terdapat di tanah tersebut, termasuk rumah adalah hak milik kaum perempuan. Keempat, perempuan sebagai pemimpin, maksudnya bundo kanduang adalah pengontrol kekuasaan; keputusan apapun yang akan diambil harus dimusyawarahkan dulu dengan bundo kanduang, termasuk keputusan politik.

Ketika Orde Baru berkuasa, dengan merubah tatanan nagari menjadi pemerintahan desa di Minangkabau melalui kebijakan UU No.5 tahun 1979, yang secara menyolok menghendaki modernisasi dan birokratisasi pemerintahan desa, negaranisasi dan marginalisasi terhadap keragaman kesatuan masyarakat hukum adat, semua kearifan lokal yang dipertahankan menjadi 
kultur adat Minangkabau berubah drastis. Nilai-nilai adat, dan fungsi-fungsi dasar dari kepemimpinan masyarakat adat mejadi hilang termasuk juga peran bundo kanduang. Melembagakan semua perangkat adat termasuk juga bundo kanduang menjadi sebuah institusi yang kemudian dinamakan organisasi bundo kanduang Sumatera Barat. Eksistensi bundo kanduang setelah dilembagakan, juga menjadi bidikan politik orde baru sebagai sarana dalam memobilitasi kaum perempuan minang untuk mendukung program pemerintah, karena dengan dilembagakannya bundo kanduang mejadi sebuah institusi dalam satu bendera yang sama dengan LKAAM tentu tidak bisa dielakkan bahwa tujuannya hanya untuk memuluskan kepentingan pemerintahan.

Peranan bundo kanduang sebagai representasi perempuan pada masa orde baru tidak jauh berbeda dengan peranan lembaga-lembaga kewanitaan bentukan orde baru lainnya, seperti Darma Wanita dan PKK. Basis programnya hanya lebih menitik-beratkan kepada seputar urusan domestik kewanitaan. Institusi bundo kanduang hanya disimbolkan sebagai basis matrilineal yang seolah tetap kokoh berdiri dan tidak luntur dalam perubahan sistem pemerintahan, padahal nyatanya institusi bundo kanduang hanya dikooptasi dan menjadi alat legitimasi politik pemerintahan Orde Baru. Proses kooptasi pemerintah Orde Baru kala itu benar-benar efektif, terbukti peran institusi bundo kanduang dominan hanya menjadi simbol dalam upacara-upacara adat dan seremonial yang seringkali diadakan oleh pemerintah.

Memasuki reformasi dan otonomi daerah dan dengan dikeluarkannya peraturan daerah No.9 tahun 2000 dan peraturan daerah nomor 2 tahun 2007 mulai memberikan kesempatan yang besar bagi perempuan untuk terlibat dalam ranah politik di nagari khususnya, dan Sumatera Barat umumnya. Dalam bingkai dan ruang otonomi tersebut, semakin memperluas tuntutan dan peran bundo kanduang di dalam pemerintahan Sumatera Barat. Dalam konteks era sekarang ini, 
bundo kanduang tidak hanya didaulat sebagai institusi yang hanya bergerak pada pelestarian adat istadat saja, tetapi secara langsung juga merambah pada bidang politik, khususnya sebagai mitra pemerintah dalam mengawasi jalannya pemerintahan.

Kumpulan-kumpulan Bundo kanduang yang kemudian bergabung kedalam bentuk sebuah Organisasi bundo kanduang, kemudian muncul sebagai sebuah kelompok yang berupaya memperjuangkan lagi peningkatan peran kaum perempuan sesuai dengan adat minangkabau. Organisasi bundo kanduang muncul sebagai representasi perempuan yang fokus dalam memperjuangkan aspirasi-aspirasi perempuan minang. Organisasi bundo kanduang mejalankan berbagai macam program dan gerakan yang ditujukan untuk mempengaruhi kebijakan sehingga nantinya kebijakan tersebut tidak merugikan perempuan. Lebih lanjut, organisasi bundo kanduang juga melakukan berbagai konsilidasi dengan aparat pemerintah serta masyarakat, terutama yang terkait dengan peningkatan program pemberdayaan kaum perempuan.

Peran organisasi bundo kanduangSumatera Barat adalah sebuah gerakan yang berpijak pada landasan ajaran agama islam yang pasti dan nilai-nilai adat dan budaya Minangkabau yang jelas. Gerakan sosio-politik organisasi bundo kanduang merupakan gerakan yang ditujukan untuk kepentingan perempuan Sumatera Barat sesuai dengan ajaran-ajaran dan norma budaya Minangkabau. Apapun usaha dan tindakan sebuah kelompok dalam memperjuangkan kepentingannya adalah sebuah tindakan kekuatan politik baik dilakukan secara langsung ataupun tidak langsung. Organisasi bundo kanduang adalah organisasi yang melingkup bidang sosial, ekonomi, budaya, bahkan politik yang tujuannya untuk mengembalikan peranan dan fungsi perempuan pada posisi sentral yang kental dalam adat matrilineal. organisasi bundo kanduang kemudian bertransformasi menjadi sebuah gerakan yang dilakukan oleh dari dan untuk perempuan. 


\section{METODE PENELITIAN}

Metode penelitian yang digunakan yaitu metode deskriptif dengan menggunakan pendekatan kualitatif. Data primer diperoleh dari wawancara mendalam (indepth interview) dengan menggunakan pedoman wawancara. untuk itu disiapkan catatan lapangan yang berguna untuk memudahkan peneliti mencatat setiap fenomena dan data yang didapatkan. Wawancara juga memungkinkan peneliti mendapat kedalaman dan kelengkapan informasi (Creswell, 2002; Danim, 2002 : 35). Selain itu juga digunakan data sekunder dari dokumen arsip dan jurnal ilmiah lainnya. Diantara para informan adalah para pengurus bundo kanduang Sumatera Barat, aleg perempuan Provinsi Sumatera Barat, aktivis perempuan, ninik mamak, dan pengurus partai. Lokasi penelitian ini adalah di Sumatera Barat.

\section{HASIL PEMBAHASAN}

\section{Bundo kanduang sebagai modal sosial dalam mendorong kehadiran Perempuan Di Lembaga Legislatif Di Sumatera Barat}

Organisasi Bundo kanduang Sumatera Barat adalah perkumpulan perempuan Minangkabau yang secara bersama-sama bergerak demi mencapai tujuan yang sama yakni meningkatkan kualitas sumber daya kaum perempuan Sumatera Barat dan generasi muda. Keberadaan Organisasi Bundo kanduang di Sumatera Barat adalah sebagai gerakan sebuah kelompok yang memperjuangkan peranan dan kedudukan sebenarnya perempuan di Sumatera Barat sesuai adat dan sistem matrilineal.

Di sistem matrilineal, pada dasarnya bundo kanduang memiliki dua karakteristik, yaitu; pertama sebagai personality, yaitu merujuk kepada karakteristik perempuan minangkabau sebagai individu memiliki tuntutan untuk berkontribus nyata dalam komunitas masyarakatnya. 
Kedua, bundo kanduang sebagai institusi yang sejajar dengan institusi lainnya, mempunyai kekuatan dan akses yang sama dalam struktur pemerintahan minangkabau (Siti Fatimah ; 16). Realita saat ini, karakteristik bundo kanduang/perempuan yang di agung-agungkan baik secara personality dan institusi dalam sistem matrilineal inilah yang saat ini sudah hilang.

Posisi sentral perempuan yang diagungkan dalam sistem matrilineal terakulturasi dengan perubahan budaya dan perkembangan zaman. Keterkukungan sistem adat pada masa orde baru, membuat tumbuh suburnya paham dan pandangan baru di dalam masyarakat Minangkabau. Acap kali pembuatan kebijakan hanya berada di pihak laki laki dan kebijakan yang dihasilkan pun tidak ramah perempuan. Peran dan partisipasi politik perempuan Minangkabau khususnya dalam lembaga formal dan informal harus diakui masih sering terabaikan. Salah satu wujud keterabaian tersebut misalnya tercermin dari rendahnya angka-angka partisipasi dan keterwakilan perempuan dalam lembaga publik baik formal maupun informal, mulai dari tingkat nagari bahkan Provinsi.

Organsisasi Bundo kanduang Sumatera Barat sebagai sebuah kelompok representasi perempuan minang yang melakukan gerakan penguatan kembali peranan dan fungsi kaum perempuan sesuai adat matrilineal kemudian hadir sebagai kasalitator, fasilitator, dan motivator penggerak untuk kehidupan adat, sosial, dan politik perempuan di Sumatera Barat. Organisasi ini berupaya meningkatkan angka keterwakilan perempuan tersebut dengan membangun kerjasamakerjasama, memberikan dukungan serta muncul sebagai sebuah modal sosial guna menghadiran kembali wakil-wakil perempuan di lembaga pengambil keputusan.

Robert D. Putnam, mendefinisikan modal sosial sebagai sesuatu karakteristik yang ada di dalam organisasi sosial, semisal kepercayaan, norma, dan jejaring yang bisa memperbaiki efisiensi masyarakat melalui memfasilitasi aksi-aksi yang terkoordinasikan. merujuk kepada 
Putnam, organisasi bundo kanduang sebagai sebuah modal sosial dalam mendorong kehadiran perempuan di lembaga pengambilan keputusan, berusaha memulai dasar gerakannya dengan membangkitkan lagi semangat, partisipasi, power hingga bargainning position perempuanperempuan yang di ruang lingkup sistem pemerintahan terkecil di Sumatera barat yakni pemerintahan nagari. Organisasi bundo kanduang bergerak menfasilitasi pemberdayaan bundo kanduang nagari atau mande soko.

Gerakan organisasi bundo kanduang dalam menguatkan kedudukan bundo kanduang adat atau Mande soko juga sebagai respon atas kesempatan politis yang diamanatkan oleh perda Nagari. Saat ini keberadaan perempuan di lembaga legislatif nagari tak lebih dari $9 \%$. Keberadaan perempuan di lembaga legislatif nagari masih bersifat sebagai pelengkap dan pendukung untuk kelancaran pengambilan keputusan/kebijakan, sedangkan pengambilan keputusan masih diangap dominasi kaum laki-laki. Perlu adanya penguatan kapasitas institusi bundo kanduang di nagari sebagai kelompok wilayah terkecil dalam sistem pemerintahan Sumatera Barat melalui pemberdayaan Mande Soko.

Bundo kanduang adat atau mande soko merupakan perempuan minangkabau yang berperan aktif ditengah kaum secara nyata. Mereka mengetahui fungsi, hak dan kewajiban sebagai perempuan minangkabau. Mande soko nagari mempunyai hak veto terhadap suatu keputusan publik yang ada di kaum, terutama jika kepala kaum tidak menjalankan fungsinya dengan baik. Mande soko kaum dianggap menjadi wadah strategis dalam mempengaruhi sebuah kebijakan. Ketika Mande soko mulai berperan dan didengarkan, maka secara tidak langsung membuka akses bagi perempuan perempuan di nagari untuk menyampaikan aspirasi, melakukan lobi dan mempengaruhi kebijakan yang dihasilkan sehinggatidak merugikan prempuan, selain itu juga membuka kesempatan dan mengembalikan power politis perempuan minangkabau yang 
selama ini hilang. Mande soko diyakini sosok paling potensial dalam menggerakan basis -basis kaum perempuan . Hal ini sesuai dengan ciri model modal sosial yang dikemukanan Coleman terkait model "Relasi Wewenang". Dengan menguatkan kembali peran dan power mande soko dalam sistem pemerintahan nagari, maka diharapkan mulai adanya output-output kebijakan yang pro kepada perempuan dimulai dari ruang lingkup pemerintahan terecil.

Sebagai organisasi yang berfungsi memperkuat kedudukan mande soko bertindak sebagai mitra pemerintah dalam mengimplementasikan dan menjalankan kebijakan peraturan daerah Sumatera Barat yang mengamanatkan ketersediaan perempuan di lembaga legislatif. Untuk mencapai tujuannya tersebut, organisasi bundo kanduang kian aktif membentuk dan menghidupkan kembali organisasi bundo kanduang di nagari yang anggotanya terdiri dari mande-mande soko. Saat ini, Sebanyak 17 daerah kabupaten/ kota telah memiliki perangkat organisasi bundo kanduang, termasuk hingga kecamatan dan nagari yang ada di dalam wilayahnya yang berjumlah kurang lebih sebanyak 760 nagari. Tak hanya itu, guna meningkatkan kapasitas perempuan di nagari, organisasi bundo kanduang juga telah melayangkan rekomendasi kepada pemerintah Provinsi untuk membangun sekolah-sekolah dan pusat pembelajaran peningkatan kapasitas dan kualitas Mande Soko.

Selain peningkatan peranan perempuan dalam lembaga pengambil keputusan di tingkat nagari, organisasi bundo kanduang pun terus berupaya mendorong dan menginginkan adanya peningkatan perempuan di lembaga pembuat keputusan yang lebih tinggi yakni kabupaten/ kota hingga Provinsi. Kurangnya wakil perempuan dalam politik formal merupakan penghambat bagi perempuan untuk mengasrtikulasikan kepentingannya. Karena dengan keadaan seperti itu, maka kebijakan-kebijakan pemerintah yang dikeluarkan menjadi kurang berpihak terhadap kepentingan-kepentingan perempuan. 
Menyadari pentingnya kehadiran perempuan di lembaga legislatif formal, selain menjadi modal sosial dalam memfasilitasi pemberdayaan perempuan, bundo kanduang kemudian hadir sebagai sebuah gerakan yang mendukung sejumlah perempuan yang ikut bertarung memperebutkan kursi dalam pemilu legislatif di provinsi sumatera barat periode 2014-2019 lalu. Bundo kanduang- bundo kanduang di nagari menjadi sebuah modal sosial yang menguntungkan dan membantu keinginan calon legislatif perempuan.

Meningkatkan keterwakilan perempuan di lembaga legislatif, harus dicapai dengan meloloskan wakil-wakil perempuan dalam perolehan suara pada pemilihan umum ditengah ketatnya dominasi laki laki. Untuk lolos di pemilihan umum, seorang calon legislatif harusnya memiliki strategi dan modal yang kuat dalam mengalahkan pesaing lainnya. Melalui wawancara dengan Koalisi Perempuan Indonesia, terdapat pengkategorian perempuan-perempuan yang berada di partai politik Sumbar yang terdiri dari beberapa macam tipe, yakni;pertama, perempuan militansi dan mempunyai posisi strategis di partai, perempuan dalam kategori ini adalah mereka yang berjibaku lama di partai, tapi mereka tidak memiliki cukup modal ekonomi. Kedua, kelompok perempuan yang memiliki modal ekonomi saja, perempuan bermodal tapi dia tidak berjibaku di partai artinya mereka tidak mengerti akan visi-misi partai dan tujuan berpolitik. Ketiga, perempuan pemenuh kuota, yakni perempuan yang sama sekali keikutsertaanya karena hubungan personal dan ikut-ikutan, tapi apa tujuan dari keterwakilan itu tidak tahu.

Hasil penelitian menunjukan bahwasanya aleg perempuan yang saat ini lolos dan berhasil duduk di lembaga legislatif Sumbar periode 2014-2019 memiliki basis modal yang berbedabeda. Ada aleg yang memiliki basis modal politik tapi sulit dalam modal ekonomi, ada Aleg 
yang memanfaatkan modal ekonomi dan sosial, atau ada aleg yang menggabungkan antara modal politik dan modal sosial, ataupun sebaliknya.

Sesuai dengan teori yang dikemukakan Francis Fukuyama (1995) bahwasanya modal sosial adalah kemampuan para individu dalam beraktivitas secara tepat untuk mencapai tujuan bersama di dalam komunitas atau organisasi. modal sosial menurut Fukuyama adalah norma informal dan bukan aturan konstitusi formal, ada aktivitas relasi antar dua orang atau lebih, ada resiprositas (hubungan timbal-balik), diwujudkan hanya dalam hubungan yang sangat erat (pertemanan) bukan hubungan formal, dan untuk pencapaian tujuan. Modal sosial yang akan digunakan caleg perempuan dalam kampanye adalah segala sesuatu yang terkait dengan relasi sosial antara calegdengan konstituen di daerah pemilihannya. Adanya kedekatan psikologis antara caleg perempuan dengan konstituennya, terlebih apabila ia caleg petahana, maka modal sosial dapat dijadikan faktor penentu pemenangan kampanye dalam suatupemilu. Salah satu yang menjadi kekuatan dalam pengumpulan suara yang memberi peluang besar terhadap caleg perempuan adalah dukungan yang berasal dari kelompok yang sama.

Hasil penelitan menunjukan bahwasanya perempuan berjuang untuk menjadi lembaga legislatif di Sumatera Barat bukanlah hal yang mudah, karena perempuan memiliki keterbatasan baik dari segi kemampuan finansial yang rendah, sekaligus menyakinkan masyarakat perempuan untuk memilih perempuan merupakan hal yang jarang dimiliki oleh caleg perempuan. Karena masyarakat masih fanatik, masih adanya pemikiran ortodoks bahwa tidak ada gunanya perempuan ikut berpolitik, maka perlu strategi lain untuk mendukung upaya caleg perempuan menang, salah satunya dengan memanfaatkan sistem matrilineal. Kemampuan memanfaatkan jaringan keluarga besar (extended family), kemampuan memanfaatkan jaringan organisasi seperti Bundo Kanduang,organisasi sayap partai, majelis taklim dan lainnya merupakan modal sosial 
yang besar yang sejatinya dimiliki caleg perempuan Sumbar, yang jika dimanfaatkan akan mampumenambah dukungan dan perolehan suara (Indah Adi Putri;168).

Selain peraturan yang mendukung keberadaan Caleg perempuan untuk bisa memperoleh suara dalam pemilu, dalam konteks lokal Sumatra Barat, terdapat modal sosial lainnya untuk meraup suara sebanyaknya, yakni masyarakat Sumbar yang bercirikan budaya lokal sistem matrilineal dan menerapkan sifat egaliter. Bahwa dua ciri spesifik ini dipercaya akan memberikan kontribusi positif bagi Caleg perempuan . Budaya matrilineal menjadi kekuatan besar bagi politisi perempuan ketika mencalonkan diri sebagai legislatif. Sejatinya dengan adanya budaya matrilineal, kaum perempuan dapat memanfaatkan posisi strategis perempuan yang dekat dengan stakeholder-stakeholder salah satunya bundo kanduang. Dengan posisi itu, para calon legislatif perempuan dapat meminta restu kepada Bundo Kanduang dan juga meminta segala masukan. Menyadari bahwasanya organisasi bundo kanduang adalah kelompok yang paling potensial mendulang suara bagi calon perempuan, organisasi bundo kanduang tak sedikit mengajak dan menghimbau anggotanya kaum perempuan untuk sama sama memilih calon perempuan, apapun partainya dengan syarat si calon perempuan itu berkualitas.

Bundo kanduang dalam mencapai peningkatan keberadaan perempuan di lembaga legslatif memanfaatkan saluran hubungan pribadi dalam sistem matrilineal. Dengan melakukan hubungan pribadi dan memnafaatkan kedudukan bundo kanduang sebagai tokoh yang didengar perkataannya di masyarakat kaum minangkabau, bundo kanduang telah menjadi modal sosial yang potensial bagi meloloskan calon calon perempuan di ajang pemilihan umum. Namun harus digaris bawahi, status bundo kanduang di Sumatera Barat tidak dapat menjadi jaminan keterwakilan perempuan di parlemen, Namun bundo kanduang dapat berperan dalam melobby anak dan kemanakan untuk mendukung perempuan caleg. Karena idealnya, kehadiran dari 
institusi Bundo kanduang bahwasanya tidak hanya mewakili keberadaan dari kaum perempuan yang ada di Nagari secara keseluruhan, tetapi juga dapat menjadi pintu masuk sebagai basis penyadaran dan peningkatan potensi yang dimiliki oleh kaum perempuan.

\section{Tabel Anggota Dewan Perwakilan Rakyat Daerah Provinsi Sumatera Barat}

\section{Periode 2014 - 2019}

\begin{tabular}{|l|l|l|l|l|l|}
\hline No & Nama aleg & Jabatan & Partai & Fraksi & Badan \\
\hline 1 & Sitti Izati & $\begin{array}{l}\text { Anggota } \\
\text { komisi I }\end{array}$ & Golkar & Golkar & Anggaran \\
\hline 2. & Riva Melda & $\begin{array}{l}\text { Anggota } \\
\text { komisi I }\end{array}$ & PDIP & $\begin{array}{l}\text { PDIP, PKB, } \\
\text { PBB }\end{array}$ & Musyawarah \\
\hline 3 & $\begin{array}{l}\text { Rahayu } \\
\text { Purwanti }\end{array}$ & $\begin{array}{l}\text { Anggota } \\
\text { komisi II }\end{array}$ & PKS & PKS & Kehormatan \\
\hline 4 & Armiati & $\begin{array}{l}\text { Anggota } \\
\text { komisi II }\end{array}$ & Hanura & Hanura & Anggaran \\
\hline 5. & Marlina Suswati & $\begin{array}{l}\text { Anggota } \\
\text { Komisi V }\end{array}$ & Golkar & Golkar & Musyawarah \\
\hline 6 & Endarmi & $\begin{array}{l}\text { Anggota } \\
\text { Komisi V }\end{array}$ & Nasdem & Nasdem & Musyawarah \\
\hline 7. & Zusmawati & $\begin{array}{l}\text { Anggota } \\
\text { Komisi V }\end{array}$ & Hanura & Hanura & $\begin{array}{l}\text { Legislasi } \\
\text { Daerah }\end{array}$ \\
\hline
\end{tabular}

Sumber: Website DPRD Provinsi Sumatera Barat

Temuan penelitian menunjukkan dari ketujuh anggotalegislatif perempuan yang berhasil duduk di lembaga legislatifhasil pemilu 2014, rata-rata memiliki modal sosial yang cukup bagus di dapilnya masing-masing. Sejumlah aleg perempuan yang duduk di legislatif Sumatera Barat mengaku bahwa keberhasilan calon perempuan terkait dengan dukungan yang mereka dapatkan dari kerabat dan keluarga mereka. Salah satu strategi dan bantuan dalam perolehan suara adalah dukungan dari lembaga adat dan jaringan kekerabatan matrilineal yang ada peran bundo kanduang di dalamnya, dengan artian lain institusi Bundo Kanduang berperan sebagai modal sosial para aleg perempuan. 
Hasil penelitian di lapangan menunjukan, dari tujuh orang aleg perempuan yang berhasil duduk di lembaga legislatif Sumatera Barat, 3 (tiga) orang menggunakan jaringan marilineal dan khususnya bundo kanduang sebagai modal sosial dalam startegi pemenangan dalam pemilihan umum lalu. Pertama, Siti Izati aleg petahana Provinsi Sumatera Barat yang menjadikan organisasi bundo kanduang sebagai modal sosial yang berpengaruh dalam pemenangannya di pemilu 2014. Sitti Izati melakukan pendekatan kepada organisasi-organisasi yang ada di tengah masyarakat dan juga melakukan pendekatan ke tokoh-tokoh masyarakat, tokoh adat dan juga melakukan pendekatan ke tokoh agama setempat. Sitti Izzati merupakan salah satu kader dan pernah menjadi pengurus organisasi bundo kanduang. Sitti Izati mengaku menjadi bundo kanduang merupakan keuntungan tersendiri yang dimiliki, terutama dalam menggaet suara melalui hubungan pribadi. Tak hanya dukungan dari sesama perempuan, statusnya sebagai bundo kanduang juga memudahkan ia untuk melobby dan mendapat dukungan dari unsur dan tokoh adat yang lain:

"Tahun 2007, Bupati Padang Pariaman sangat care dengan saya, kemudian saya dimasukan menjadi wakil sekretaris bundo anduang Kabupaten Padang Pariaman, selaku pengurus bundo kanduang saya ikut rapat rapat, waktu turun ke kecamatan bahkan sampai ke nagari saya minta dukungan sama ibu-ibu dan pengrus bundo kanduang. Karena saya pengurus kabupaten, kan saya melakukan pembinaan ke kecamatan, waktu itu saya minta dukungan dan didukung. alhamdulillah meski saya ditarok nomor urut 6 tapi saya berhasil lolos. Bundo kanduang memiliki peranan yang besar di tengah masyarakat. Dalam Pemilu 2014 lalu, pengaruh bundo kanduang cukup besar dalam memengaruhi anggota kaum tentang calon legislatif yang akan dipilih. "kalau yang begitu besar perannya adalah etek uni, saudara perempuan mama ibuk, dia tokoh bundo kanduang yang aktif di kaum nagari. Dia ikut mempersiapkan pertemuanpertemuan, melobby perempuan perempuan yang lain di kampung dan se kaum tuak maminta restu untuak uni".

Selain Sitti Izzati, Aleg kedua yang menggunakan jaringan matrilineal dalam modal kemenangan saat pemilu yakni Marlina Suswati. Strategi yang dilakukan Marlina Suswati dilakukan mengunakan jalur kekeluargaan. Dimana ia menghimpun pemilih dengan 
menggunakan ikatan kekeluargaan. Marlina Suswati memanfaatkan sistem matrelineal yang ada di sumatera Barat. Marlina mendekati dan menggunakan lobby dengan lembaga-lembaga adat seperti ninik mamak, bundo kanduang dan lainnya. Sistem kekerabatan matrilineal menjadi salah satu strategi yang di rencanakan oleh Marlina Suswati. Dengan memanfaatkan garis keturunan dari ibu, memanfaatkan fungsi-fungsi bundo kanduang dan ninik mamak, Marlina membuka jaringan yang luas untuk memperluas dukungannya.Dengan memanfaatkan sistem kekerabatan matrilineal memudahkan Marlina Suswati mencari target-target pemilihnya.

Ketiga yakni Armiati, caleg dari partai Hanura. Ia sudah menjadi kader Hanura dari tahun 2006, sejak Hanura pertama kali lahir di Kota Padang. Pada tahun 2010 suaminya meninggal, dan Armiati harus berjuang sendiri. Sempat terpikir untuk ia berhenti, namun pihak-pihak dari kaum matrilineal termasuk bundo kanduang selalu memberikan dukungan hingga akhirnya ibu Armiati menang. Pihak matrilineal sangat membantu menyebarkan informasi mengenai dirinya dari rumah ke rumah, ibu ke ibu, suami ke suami. Para kaum mengumpulkan masanya dan ibu armiati berbicara di depan mereka untuk menyakinkan masyarakat luas terkhusus perempuan.

Sistem kekerabatan Matrilineal dikenal sebagai sistem kekerabatan yang kental. Peranan tokoh adat di Minangkabau masih diperhitungkan oleh masyarakatnya, terutama bundo kanduang. Sehingga dengan adanya sistem Matrilineal tersebut, terbentuk jaringan-jaringan yang dapat memperluas basis suara yang akan dicapai,dan organisasi bundo kanduang dalam mendorong peningkatan perempuan di lembaga kebijakan menjadi jaringan kekerabatan yang paling potensial bagi mendulang suara perempuan. Posisi bundo kanduang yang sentral dalam adat pada kedudukannya di nagari, memudahkannya untuk mendorong keberpihakan dan dukungan pada aleg perempuan. 
Bundo kanduang adalah perempuan-perempuan yang suara serta perintahnya didengar oleh anak kemenakan, dan juga sangat potensial dalam melobby sanak keluarga lainnya. Adapun Bundo kanduang yang paling potensial dalam menjadi modal sosial aleg perempuan adalah bundo kanduang adat/ mande soko. Organisasi bundo kanduang Sumatera Barat selain memberikan dukungan secara institusi terhadap keberadaan perempuan dalam ajang pemilihan umum, juga sebagai pendorong keaktifan dan penguatan kedudukan bundo-bundo kanduang adat di nagari sehingga ketika mempunyai power dalan menjaring basis masa dan dukungan bagi para caleg perempuan.

Organisasi bundo kanduang memanfaatkan posisinya di dalam adat matrilineal untuk melakukan sejumlah lobi, tawar menawar, hubungan pribadi maupun tuntutan terhadap kelompok lainnya di dalam sistem politik agar membuka askses selebar-lebarnya guna menghadirkan perempuan di lembaga pengambil kebijakan. Organisasi bundo kanduang mendorong partai politik mengusung calon-calon perempuan yang berkualitas. Organisasi bundo kanduang mendesak perubahan proses rekruitmen parpol dalam menjaring caleg-caleg perempuan. Partai politik di Sumatera Barat diharapkan melakukan uji kualitas kader perempuan sebagai salah satu syarat dalam mengusulkan calon perempuan dalam pemilihan mendatang, Hal ini ditujukan agar perempuan yang ikut dalam pemilihan nantinya mampu berdaya saing tinggi, sehingga memiliki potensi yang besar untuk menang. Caleg perempuan bukan hanya jadi pelengkap penderita, tapi caleg perempuan yang diusung parpol harus memiliki kredibelitas dan kualitas sehingga dipercaya rakyat dan mampu meningkatkan kepercayaan publik terhdapat keberadaan perempuan dalam lembaga pembuat kebijakan. 


\section{2.. Tantangan Yang Di Hadapi Bundo kanduang Dalam Mendorong Keterwakilan Di}

\section{Sumatera Barat}

Representasi perempuan dalam politik masih jauh dari harapan. Kenyataan tersebut kian ditunjang denga angka- angka keterwakilan perempuan di lembaga kebijakan yang masih menunjukan posisi stagnant. Jumlah perempuan yang memadai pada institusi pengambil keputusan akan membuat pergeseran pada cara pandang dalam menyelesaikan masalah-masalah politik dengan memasukan unsur pemikiran dari perempuan. Selain itu, akan dihasilkan pula perubahan kebijakan dan peraturan perundangan yang dapat memasukkan kebutuhan khusus perempuan. Namun pada kenyataanya, keberadaan para aleg perempuan yang duduk di DPRD Sumbar dalam struktur kedewanan belum pernah satupun yang duduk dan menjabat di kursi ketua pimpinan. Aleg perempuan hanya berjibaku di bangku anggota dan kurang berada di posisi startegis, sehingga keberadaan wakil perempuan di lembaga legislatif masih belum terwakilkan baik secara kuantitas ataupun kualitas.

Pada dasarnya tidak ada halangan dan hambatan bagi perempuan minangkabau untuk terjun ke dalam politik. Hal ini dijamin secara pasti di dalam sistem adat matrilineal yang menjadi norma prilaku dan pola hidup masyarakat Sumatera Barat yang saat ini tengah di upayakan oleh organisasi bundo kanduang. Namun dalam prakteknya, tidak sedikit kendala yang harus dihadapi dalam mendorong representasi perempuan di lembaga legislatif Sumbar, baik berasal dari, faktor Intern. dan faktor ekstern seperti budaya dan agama, hingga dualisme sistem pemerintahan yang berlaku di Sumatera Barat

\section{a. Hambatan Intern.}

Faktor intern adalah faktor yang berasal dari dalam tubuh organisasi bundo kanduang dalam melaksanakan fungsinya dan sumber daya yang dimiliki untuk mendukung dalam 
melaksanakan fungsinya. Sumber daya adalah suatu nilai potensi yang dimiliki sebuah lembaga atau organisasi. Menurut Hrebenar dan Scott, sumber daya meliputi; sumber daya fisik, sumber daya organisasi, sumber daya politik, dan sumber daya motivasi.

Pertama, sumber daya fisik. Menurut Hrebenar dan Scott sumber daya fisik terdiri dari adanya dana dan anggota. ketersedian sumber daya keuangan akan sangat mempengaruhi keberhasilan dalam melaksanakan fungsi pada suatu lembaga ataupun organisasi. Disamping pelaksanaan fungsi yang tidak maksimal, keterbatasan anggaran akan menyebabkan kinerja dari suatu lembaga akan menjadi rendah sehingga kegiatan yang direncanakan tidak akan sesuai dengan apa yang diharapkan. Organisasi Bundo kanduang Sumatera Barat saat ini harus berjalan diatas keterbatasan finansial dan tanpa ada sarana dan prasarana yang menunjang. Paska gempa 2009, bangunan kantor Lembaga Bundo kanduang rusak parah dan sangat riskan untuk dipergunakan . Akibatnya sekretariat sementara harus dipindahkan ke rumah salah satu anggota. Kondisi ini menyebabkan arsip dan dokumen-dokumen kerja tidak terkumpul lengkap. Ketiaadaan sekretariat ini membuat Organisasi Bundo kanduang kesulitan dalam melakukan rapat-rapat kerja, yang mana rapat kerja tersebut penting untuk membahas strategi dan tujuan yang harus dilakukan organisasi bundo kanduang.

Sementara itu dari segi Anggaran, Organisasi bundo kanduang dalam melaksanakan kegiatannya memperoleh dana rutin dari Pemerintah Daerah Provinsi Sumatera Barat. Pada tahun 2011 , 2012 ,tahun 2014 bundo kanduang mendapat dama sebesar Rp. 750.000.000,(Tujuh ratus lima puluh juta rupoah) dan dari PT Semen Padang dari bulan Agustus sampai bulan Juni 2014 sejumlah Rp.105.000.000,- (Seratus lima juta rupiah) sehingga semuanya berjumlah Rp. 855.000.000,- (delapan ratus lima puluh lima juta rupiah). Sesuai dengan program kerja dana tersebut telah dimanfaatkan organisasi bundo kanduang ; 
1. Pembinaan dan penguatan kelembagaan adat dan organisasi sebesar Rp. 291.296.910,-

2. Memelihara, melestarikan ABS-SBK sebesar Rp. 56.345.000,-

3. Meningkatkan kualitas kaum perempuan dan generasi muda sebesar Rp. 328.980.150,-

4. Meningkatkan jejaring dan kerjasama dengan berbagai instansi, lembaga dan organisasi sebesar Rp 37.462.000,-

5. Meningkatkan ketahanan keluarga dalam memerangi penyakit masyarakat sebesar Rp 40.210.000,-

6. Biaya operasional sebesar Rp. 121.379.425,-

Dana yang diperoleh pada tahun 2012-2015 tersebut cenderung kecil dibanding dengan kebutuhan yang harus dipenuhi oleh organisasi. Bahkan pernah pada tahun 2017 bundo kanduang tidak mendapat bantuan anggaran. Pada tahun 2018, organisasi bundo kanduang mendapat bantuan dana sebesar 120 juta rupiah. Ketiadan dana yang didapat oleh organisasi bundo kanduang membuat sejumlah program dan kebijakan yang harusnya dilakukan bundo kanduang dalam upaya peningkatan peran kaum perempuan sesuai dengan adat minangkabau tidak dapat terlaksana.

Kedua, sumber daya Organisasi. Organisasi Bundo kanduang adalah organisasi perempuan yang sistem keanggotaannya terbuka, namun dalam hal kepengurusan, organisasi bundo kanduang Sumbar cenderung tertutup dan kaku. Dilihat dari latar belakang pendidikan, pengurus organisasi bundo kanduang adalah orang orang yang berpendidikan tinggi, ini sesuai dari gelar yang dimiliki. Organisasi bundo kanduang pun memiliki berbagai macam latar belakang profesi, mulai dari dosen, guru, wirausaha, PNS, dan lainnya. Dari segi usia, sebagian besar pengurus organisasi bundo kanduang umumnya sudah berusia matang dan tua. Organisasi 
bundo kanduang menyakini memiliki anggota yang berasal dari kaum terdidik, dan memiliki keintelektualan yang tinggi dan cukup berbobot dan berkualitas.

Ketiga, Sumber daya politik yakni pemahaman lembaga akan proses politik yang berlangsung dan reputasi atau prestise yang dimiliki lembaga beserta anggotanya. Salah satu yang mejadi faktor internal berhasil tidaknya bundo kanduang dalam mendorong keterwakilan perempuan adalah terkait dengan sumber daya politik yang dimilikinya. Penelitian di lapangan menunjukan pemahaman politik organisasi bundo kanduang relatif masih lemah. Fitriani, pengurus Koalisi Perempuan Indonesia Sumatera Barat dalam kajiannya tentang bundo kanduang menyebutkan bahwa organisasi bundo kanduang memiliki masalah dalam prespektif melihat permasalahan perempuan dan politik. Perempuan yang duduk di dalam tubuh organisasi bundo kanduang adalah mereka yang memiliki status dan kedudukan yang bagus dari segi adat dan ekonomi, namun tidak memperhatikan apakah perempuan itu berkualitas bahkan mengerti tentang permasalahan perempuan. Pengurus organisasi bundo kanduang memiliki tingkat pendidikan yang tinggi, namun pendidikan tersebut bukan jaminan untuk mengukur cara pandang perempuan-perempuan tersebut dalam melihat perubahan permasalahan perempuan ataupun sistem politik.

Organisasi Bundo kanduang tidak memiliki anggota atau pengurus yang memiliki latar belakang pendidikan politik yang tinggi. Pengurus yang duduk di dalam lembaga bundo kanduang adalah mereka yang paham tentang adat, tapi tidak terlalu militan dan "melek" akan isu-isu pergerakan perempuan di dalam politik. Ketidak-cakapan serta ketertutupan organisasi bundo kanduang terhadap masalah -masalah politik membuat organisasi bundo kanduang justru tidak berniat untuk ikut serta menggiring isu perempuan terutama yang berbau politik bahkan membuat daya tawar bundo kanduang lemah ketika berhadapan dengan institusi-institusi politik 
lainnya. Terkait untuk persoalan menghadirkan keterwakilan perempuan baik secara kuantitas maupun kualitas, organisasi bundo kanduang kurang menunjukan sebuah desakan, tapi hanya berupa himbauan dan rekomendasi. Ketua Organisasi bundo kanduang Sumatera Barat mengakui bahwa dalam tubuh organisasi bundo kanduang merasa tidak memiliki tanggung jawab atau kewajiban terkait kapasitas aleg untuk mengerti urusan adat, ataupun fokus dalam menghadirkan perempuan di wilayah politik. Organisasi bundo kanduang justru menuntut bahwa aleg itu sendirilah yang harus menambah dan memperluas kemampuan nya dengan meminta advice ke bundo kanduang.

Pada dasarnya, kedudukan lembaga bundo kanduang yang berada diantara pemerintah dan masyarakat, seharusnya mampu menciptakan isu-isu baru sebagai umpan bagi munculnya aspirasi dari masyarakat. Organisasi bundo kanduang seharusnya tidak pasif, tidak sekedar menunggu munculnya isu atau aspirasi dari masyarakat namun dituntut berperan aktif menciptakan isu-isu baru sebagai umpan bagi munculnya aspirasi dari masyarakat. Orgnisasi bundo kanduang yang terorganisir dan memiliki nilai-nilai adat matrilineal yang mengakar pastinya mampu melihat isu-isu yang sedang terjadi di kalangan masyarakat terutama soal perempuan. Berdasarkan informasi yang didapat dari Organisasi Bundo kanduang Sumatera Barat, organisasi bundo kanduang telah membuat berbagai macam isu tentang perempuan, namun belum berbicara dan menfokuskan kepada masalah representasi perempuan di lembaga legislatif Sumatera Barat. Isu-isu yang dibuat dan dijadikan fokus utama masih berada di tataran isu sosial, budaya dan adat.

Keempat, Sumber daya motivasi, yakni menunjuk kepada komitmen yang dipegang oleh lembaga, semakin tinggi komitmen akan semakin memotivasi anggota kelompok menyampaikan atau menyalurkan aspirasi masyarakat yang diwakilinya. Tinggi rendahnya motivasi suatu 
kelompok dalam menyuarakan aspirasinya terutama soal keterwakilan perempuan, disebabkan oleh berbagai macam faktor, seperti paradigma dan budaya yang di anut, keinginan, agama, dan sikap mental organisasi tersebut.

Direktur Women's Crisis Centre Nurani Perempuan (WCC Nurani Perempuan) Sumatera Barat, Yefri Heriani yang bergerak dalam bidang pemberdayaan perempuan di bidang publik pun menemukan kondisi tentang organisasi bundo kanduang. Kritikan terhadap organisasi bundo kanduang yang dinilai belum optimal dalam melakukan perannya sebagai satu satunya organisasi representasi perempuan minangkabau yang kuat sistem matrilinealnya. Kontruksi ideal masyarakat politik Minangkabau kenyataanya masih menyimpan ambivalensi sosial kultural. Para elit lokal yang berperan dan berpengaruh di Sumbar termasuk bundo kanduang, belum bertanformasi secara total. Secara politik, pragmatisme politik warisan orde baru masih terimplikasi hingga saat ini. Berpuluh-puluh tahun, menjadi alat kepentingan politik orde baru yang kental budaya pathriarki, membuat corak dan cara pandang bundo kanduang masih memakai paradigma lama.

Hal ini Terlihat dari, Pertama kultural, meskipun masyarakat organisasi bundo kanduang menggaungkan Sumatera Barat (Minangkabau) menganut sistem matrilineal namun budaya patriarki dalam kekuasaan masih cukup berpengaruh. Kekuasaan sebenarnya tetap berada pada laki-laki. Selama ini, perilaku politik dipandang sebagai aktifitas maskulin yang memerlukan suatu keberanian, kemandirian, kebebasan berpendapat dan tindakan agresif. Paradigma di dalam pengurus organisasi bundo kanduang masih didominasi adanya anggapan bahwa perempuan lebih mementingkan perasaan daripada rasionalitas dalam menghadapi persoalan. Jeratan budaya patriarkhi juga turut mengekang perempuan untuk tidak tampil ke ranah politik. Untuk keterwakilan perempuan di Minangkabau masih sama seperti di daerah lain, karena memang 
masih ada cara berpikir masyarakat yang berpikir bahwa wanita hanya berada di area domestik bukan di wilayah publik. Fokus pemikiran organisasi bundo kanduang tentang Budaya matrilineal hanya meninggikan kepada aspek domestik yakni suku dan harta kaum, tapi dalam hal politik itu tidak dirasakan. Perempuan hanya dihargai di ranah sosial budaya ketimbang di ranah politik.

Masih adanya kecenderungan bundo kanduang menutup diri terhadap isu-isu perempuan yang kian mengemuka di domain politik. Dalam paradigma pemikiran bundo kanduang hanya mengusung bagaimana posisi sentral perempuan di adat, tanpa memperhatikan dan menghubungkan isu dan kebijakan perempuan dari kacamata politik formal. Perempuan menurut organisasi bundo kanduang adalah bagaimana ia bisa berfungsi sesuai ABS-SBK, yakni yang hanya memiliki peranan adat nan sabana adat, adat nan diadatkan, adat teradat dan adat istiadat, sebagai berikut: Pertama manuruik alua nan luruih (menurut alur yang lurus), kedua, manampuah jalan nan pasa (menempuh jalan yang pasar), ketiga memeliharo harato dan pusako (memelihara harta dan pusaka), keempat mamaliharo anak kamanakan (memelihara anak kemenakan). Saat ini untuk struktur kepengurusan bundo kanduang sendiri saat ini masih berada dibawah wilayah laki-laki, yakni dibawah pembinaan LKAAM.

Selain budaya patriarki, rendahnya motivasi organisasi bundo kanduang dalam melakukan gerakan mendorong keterwakilan perempuan berasaldari internal perempuan itu sendiri. Penghargaan yang besar terhadap laki-laki masih melekat di pribadi perempuan sehingga hingga saat ini perempuan cenderung untuk mengikuti keputusan yang diambil pihak laki-laki. Perempuan-perempuan yang menjadi bundo kanduang masih enggan ikut serta di dalam wilayah politik. Hal ini seperti pernyataan Ketua Umum bundo kanduang; 
"Bukannyo urang minang atau padusi minang apolai bundo-bundo kanduang indak ado yang hebat, banyak yang hebat, tapi urang tu ndak mamiliah untuak jadi anggota dprd,Kemungkinan, karena secara budaya ia sudah kuat dan mempunyai peranan yang jelas sebagai bundo kanduang. Sehingga, politik menjadi tidak menarik bagi para perempuan Minang."

Kedua, Masalah selanjutnya yang menyebabkan rendahnya sumber daya motivasi dari bundo kanduang dalam mendorong keterwakilan perempuan di lembaga kebijakan adalah interpretasi terhadap ajaran agama yang menganggap bahwa perempuan tidak dapat jadi pemimpin. Masyarakat Minangkabau yang menganut ajaran agama Islam yang sangat kuat, menginterpretasikan bahwa perempuan tidak pantas untuk terlibat dalam masalah kepemimpinan dan politik masih mengakar kuat. Organisasi bundo kanduang merupakan orgnisasi yang mensyaratkan untuk mejadi pengurus maupun anggota adalah perempuan yang beragama islam. Di dalam ajaran islam, otoritas kepemimpinan itu berada di tangan laki-laki. Seorang perempuan minangkabau adalah perempuan yang harus taat terhadap ajaran islam. Dan di Islam, setiap perempuan dalam beraktivitas termasuk politik harus meminta izin ke pemimpinnya, jika belum bekeluarga izin terletak pada ayah, sementara jika ia sudah bekeluarga wajib memperoleh izin dari sang suami.

Ketiga, masalah selanjutnya yang berpengaruh tehadap rendahnya motivasi organisasi bundo kanduang dalam mendorong keterwakilan perempuan adalah persoalan sikap mental. Adanya kekecewan dan ketidakpercayaan yang dimiliki oleh bundo kanduang terhadap para aleg-aleg perempuan membuat ketidak bulatan motivasi untuk mendukung perempuan. Upaya mendorong keterwakilan perempuan di lembaga bundo kanduang dilaksanakan hanya sebagai amanat dari fungsi organisasi sebagai mitra dalam mensukseskan pembangunan daerah. Sebagian anggota bundo kanduang menilai perlu mendorong calon perempuan, sebagian lagi menganggap mendukung aleg perempuan adalah pekerjaan yang sia-sia, bahkan beberapa Bundo 
kanduang mengaku tidak terlalu ambil pusing akan hal tersebut. Karena, ada atau tidak adanya perempuan yang duduk di parlemen, mereka tetap tidak menaruh perhatian terhadap kepentingan perempuan.

Ketika ditelusuri lebih dalam, antipati bundo kanduang terhadap aleg perempuan muncul karena adanya kekecewaan atau runtuhnya kepercayaan bundo kanduang terhadap aleg yang diharapkan bisa memperjuangkan perempuan Sumatera Barat. Bundo kanduang menceritakannamun dirahasiakan oknumnya — bahwa pernah suatu ketika terdapat perempuan yang duduk di DPRD Provinsi Sumbar. Selama dia memangku jabatan sebagai, katanya, wakil rakyat, dia tidak pernah mendatangi Bundo kanduang untuk berkonsultasi terkait permasalahan perempuan di Sumbar. Tentu ini meninggalkan kekecewaan kepada Bundo kanduang, karena mereka (legislator perempuan) seharusnya datang ke Bundo kanduang guna menginventaris permasalahan-permasalahan perempuan di Sumbar, namun sampai ke akhir periodenya, oknum tersebut sama sekali tidak pernah melakukan kunjungan kerja ke Bundo kanduang.

Organisasi bundo kanduang menganggap keberadaan wakil perempuan di lembaga legislatif tersebut hanya dalam tataran representasi kehadiran. kehadiran para calon perempuan hanya sebatas wakil partai bukan wakil rakyat, yang berimplikasi diabaikannya gagasan kelompok minoritas. Runtuhnya trust building organisasi bundo kanduang terhadap keberadaan perempuan di lembaga legislatif. Minimnya motivasi organisasi bundo kanduang di dalam upaya mendorong keterwakilan perempuan juga menjadi kritik sekaligus hambatan yang kian menambah deretan masalah upaya peningkatan perempuan di Sumatera Barat.

Masih kurangnya motivasi organisasi bundo kanduang dalam mendorong keterwakilan perempuan menjadi tantangan dan hambatan yang berasal dari dalam diri bundo kanduang itu sendiri. Dalam kenyataanya, dukungan organisasi bundo kanduang terhadap aleg perempuan 
masih bersifat tebang pilih berdasarkan adanya kerjasama politik, hubungan kekerabatan dan orang-orang yang dinilai mampu memberikan imbal-balik kepada organisasi bundo kanduang.

Ironisnya, meski menginginkan penguatan kembali peran perempuan, namun di dalam tubuh organisasi bundo kanduang sendiri telah terdapat pelarangan bagi setiap anggota untuk terlibat pada kepengurusan partai politik. Syarat ini menjadi mutlak dilaksanakan ketika seorang ingin atau berniat bergabung masuk ke dalam organisasi bundo kanduang. Organisai bundo kanduang merasa perlu menjaga kenetralan ditengah banyaknya kepentingan politik yang ada. Pengalaman buruk di masa lalu ketika organisasi bundo kanduang hanya dijadikan kendaraan politik oleh salah satu partai politik tertentu membuat bundo kanduang memagari dirinnya untuk terjebak kedalam situasi yang sama. Namun pemagaran diri bundo kanduang ini terkesan "kebablasan". Karena pada dasarnya, boleh -boleh saja menjaga kenetralan organisasi dari kepentingan politik manapun, tapi sebagai salah satu organisasi representasi perempuan minangkabau, organisasi bundo kanduang sudah seharusnya ikut mempunyai andil dalam mendorong kehadiran perempuan kembali di ranah publik demi mencapai kesejahteraan perempuan. Namun dalam kenyataanya, tak banyak yang bisa diupayakan oleh organisasi bundo kanduang.

\section{b. Hambatan Ekstern.}

Saat ini di Provinsi Sumatera Barat, isu tentang keterwakilan perempuan belum menjadi isu yang sentral dan mengemuka. Pemerintah yang berkuasa, baik dari tingkat nagari hingga provinsi jarang memunculkan isu dan kebijakan yang terkait dengan kepentingan dan aspirasi lembaga bundo kanduang selama ini. Dimana isu tentang perempuan di Sumatera Barat belum dijadikan isu penting, aspirasi terkait masalah perempuan hanya ditampung dan belum memiliki solusi berupa peraturan ataupun hukum yang mengikat. Dari tahun 2010 hingga 2017, selain 
perda nagari, hanya ada 5 perda lainnya yang memuat kepentingan perempuan dan itupun hanya berpusat permasalahan perempuan secara umum bukan untuk keterwakilan politik, seperti Perda No. 10 tahun 2011 tentang Penyelenggaraan Jaminnan Kesehatan SakatoPerda No. 5 tahun 2013 tentang Penanggulangan HIV-AIDS, Perda No. 5 tentang Pelindungan Perempuan Dan Anak , Perda No. 6 2014vtahun tentang Penguatan Lembaga Adat dan Pelestarian Nilai Budaya Minangkabau dan Perda No. 152014 tentang Pemberian Air Susu Ibu Eksklusif,

Hambatan ekstern berikutnya adanya persoalan kebebasan yang dimiliki oleh bundo kanduang didalam upaya mendorong keterwakilan. Masih terdapat sederet larangan-larangan perempuan untuk terjun dan megurusi masalah politik yang justru berasal dari kontruksi masyarakat Minangkabau itu sendiri. Berbicara mengenai otonomi dan kebebasan organisasi bundo kanduang, secara formal pemerintah telah memberikan kesempatan dan didukung oleh sejumlah peraturan-peraturan. Namun dalam praktiknya, baik ditingkat elit maupun masyarakat secara personal masih belum memberikan ruang selebar-lebarnya bagi pergerakan perempuan. Kondisi ini disebabkan bahwa di Sumatera barat masih kental melekatnya budaya patriarki yang dibawa oleh orde baru dan adanya stigmasisasi bahwa politik itu adalah milik laki laki, perempuan hanya soal wilayah domestik, sedangkan pengambilan keputusan masih diangap dominasi kaum laki-laki.

Kultur patriarkhi ini tidak hanya di pahami oleh kaum laki-laki saja, tetapi kaum perempuan sendiri pun di Sumatera Barat memiliki pemahaman yang sama. Budaya patriarki juga merasuk kedalam intitusi-institusi politik lainnya yang menjadi mitra bundo kanduang dalam hal mndorong keterwakilan perempuan, salah satunya adalah partai politik. Kekuasaan dominasi laki laki di parpol tak jarang menempatkan prempuan hanya sebagai pelengkap kuota 
dan di letakkan di nomor urut besar, sehingga menyulitkan perempuan ketika bersaing di ajang pemilihan umum. seperti yang di ungkapka Sitti Izati :

"Pada saat itu masih berdasarkan nomor urut. pada waktu itu ibuk juga bingung dan merasa ragu kenapa harus mencaleg, karena ibu secara pendanaan tidak kuat, waktu itu nomor urut 7. Pada tahun 2009 dicalegkan lagi pada nomor urut 3,pemilihan berdasarkan suara terbanyak. alhamdulillah terpilih. kemudian 2014 dibagi dua agam bukitinggi dibagi dua, sisa 7 kursi, sulit partai golkar dapat kursi, saya waktu itu nomor urut 4, waktu dpt nomor 4 , waktu itu saya merasa marah kecewa sedih, karena saya anggota dprd, wakil ketua, tapi ditaroh di nomor urut 4, malu juga. tapi masyarakat mendorong, katanya mau nomor urut apapun, ibu Siti harus turun."

\section{Tabel Daftar Perempuan Terpilih Pemilu 2014 Provinsi Sumatera Barat}

\begin{tabular}{|c|c|c|c|c|c|c|c|c|c|}
\hline \multirow[b]{2}{*}{ Na. } & \multirow[b]{2}{*}{ NAMA } & \multirow[b]{2}{*}{ PARTAI } & \multirow[b]{2}{*}{ NO. URUT } & \multirow[b]{2}{*}{ DAPRL } & \multicolumn{4}{|c|}{ irvonum } & \multirow[b]{2}{*}{ KETERANGAN } \\
\hline & & & & & DPR & OPD & $\begin{array}{c}\text { DPRD } \\
\text { PROVINSI }\end{array}$ & $\begin{array}{c}\text { DPRD } \\
\text { KAB/KOTA }\end{array}$ & \\
\hline 1 & 2 & 3 & 4 & 5 & 6 & 7 & 8 & 9 & 10 \\
\hline 1 & Beth Shadiq Pasadigoe, SE, Ak.MM & Golkar & 6 & Sumbar I & $\mathrm{v}$ & & & & Kab. Tangh Datar \\
\hline 2 & Hi. Emma Yohana & Golkar & 5 & Sumbar I & & $\mathrm{v}$ & & & Kota Padang \\
\hline 3 & Dra. Hj. Sinti Izzati Aziz & Golkar & 4 & II & & & $\mathbf{v}$ & & Prov Sumbar \\
\hline 4 & Endarmy & Nasdem & 1 & II & & & $\bar{v}$ & & Prov Sumbar \\
\hline 5 & Dra. Armiab & Hanura & 1 & III & & & $\mathbf{v}$ & & Prov Sumbar \\
\hline 6 & Riva Melda & pol-p & 1 & IV & & & $\bar{v}$ & & Prov Sumbar \\
\hline 7 & Zusmawab, SE, MM & Hanura & 1 & IV & & & $\bar{v}$ & & Prov Sumbar \\
\hline 8 & Marling Suswab & Golkar & 6 & $\mathrm{vI}$ & & & $\mathrm{v}$ & & Prov Sumbar \\
\hline 9 & Yuhild, Darmis, SE & ppp & 9 & 1 & & & & $\mathrm{v}$ & Kota Padang \\
\hline 10 & Gustin Pramong, S.PE & Demolorat & 2 & I & & & & $\mathrm{v}$ & Kota Padang \\
\hline 11 & Melinda Roese, SE & Nosdem & 2 & $\mathrm{I}$ & & & & $\mathrm{v}$ & Kota Padang \\
\hline 12 & Dan Anggraini Oiktavia, S.Soe, M.Si & Nasdem & 2 & II & & & & $\mathrm{v}$ & Kota Padang \\
\hline 13 & Dewi Suganti & Gerindra & 9 & III & & & & $\mathrm{v}$ & Kota Padang \\
\hline 14 & Ely Thrisyandi, SE, Akt & Gerindra & 1 & III & & & & $\mathrm{v}$ & Kota Padang \\
\hline 15 & Mla Kartika, A.Md & $p \rho p$ & 9 & III & & & & $\mathrm{y}$ & Kota Padang \\
\hline 16 & Fitoi Nora, A.Md & Gerindra & 2 & II & & & & $\mathrm{v}$ & Kota Pariaman \\
\hline 17 & MESRA & Gerindro & 1 & 1 & & & & $\mathrm{v}$ & Kota Padang Panjang \\
\hline 15 & GUSNAWATI, S.Pd & Demoliat & 3 & 1 & & & & $\mathrm{v}$ & Kota Padang Panjang \\
\hline 19 & PUII HASTUTL, A.MA & Demolerat & 1 & II & & & & $\mathrm{v}$ & Kota Padang Paniang \\
\hline 20 & Hi. LASTRT, AMS Keb & $p \rho p$ & 2 & II & & & & $\mathrm{v}$ & Kota Padang Panting \\
\hline 21 & Ir. W., AISYAH & Demokrat & 2 & II & & & & $\mathrm{v}$ & Kota Bukittinggi \\
\hline 22 & Hi. NURSYIDA, A.Ma.Pd & Demokrat & 2 & III & & & & $\mathrm{v}$ & Kota Bukbttinggi \\
\hline 23 & WULAN DENURA, A.Md Keb & Genindra & 9 & 1 & & & & $\mathrm{v}$ & Kota Payakumbuh \\
\hline 24 & HURISNA JANAUR, S.PD & PAV & 2 & III & & & & $\mathrm{v}$ & Kota Payakumbuh \\
\hline 25 & H., NURNISNA, SH & Golkar & 6 & 1 & & & & $\mathrm{v}$ & Kota Solok \\
\hline 26 & WUUAN MAYA SAR! & Nasdem & 5 & 1 & & & & $\mathrm{v}$ & Kota Sawahlunto \\
\hline 27 & ELFIA RITA DEWI, SH & Golkar & 1 & II & & & & $\mathrm{v}$ & Kota Sawahlunto \\
\hline 28 & EKA WAMMU, SE & PKPI & 6 & III & & & & $\mathrm{v}$ & Kota Sawahlunto \\
\hline 29 & Ir. NELDASWENTI, M.Si & PPP & 1 & III & & & & $\mathrm{v}$ & Kota Sawghiunto \\
\hline 30 & Fetmadami & POIP & 3 & $\mathrm{I}$ & & & & $\mathrm{v}$ & Kab. Pessel \\
\hline 31 & Sn Kumgla Dewi & POIP & 3 & III & & & & $\mathrm{v}$ & Kab. Pessel \\
\hline 32 & Emiwab, SE & Hanura & 2 & III & & & & $\mathrm{v}$ & Kab. Pessel \\
\hline 34 & | MER:OEAWATI, AMB & Wxs & 9 & III & & & & $\mathrm{v}$ & Kas Padang Paniman \\
\hline 3 & 2OERLA, SP, MM & Demolarat & 3 & $\mathrm{v}$ & & & & $\mathrm{v}$ & $\mathrm{Kab}, \mathrm{Agam}$ \\
\hline 36 & ruvised, S.AS & Geninga & 2 & $\mathrm{sV}$ & & & & $\mathrm{v}$ & Kab, Vasaman Barat \\
\hline 97 & Suct nuta SH & Golkar & 5 & H & & & & $\mathrm{v}$ & Kab, Pasaman \\
\hline 8 & MUSLIARA & $\cos$ & 2 & H & & & & $\mathrm{v}$ & Kab, Vasaman \\
\hline 39 & Ora. BIDHAWATI & POO & 2 & II & & & & $\checkmark$ & Kab. 50 Kota \\
\hline 40 & OEEWA ERMAMF, S.P. & Golkar & 6 & 1111 & & & & $\mathrm{v}$ & $\mathrm{Kab} .50 \times 000$ \\
\hline 41 & AIDA, SH & Demobat & $\frac{1}{1}$ & $\mathrm{IV}$ & & & & $v$ & $\mathrm{Kab}, 50 \times 000$ \\
\hline 42 & pre- octina & Demolerat & 2 & $\frac{\mathrm{N}}{\mathrm{s}}$ & & & & $\mathrm{v}$ & Kab, tanah oatar \\
\hline 43 & 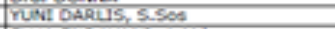 & Ramura & 9 & III & & & & $\mathrm{v}$ & Kab. Tanah Dotar \\
\hline 4 & FLVA ENOAYraNt, 2MS & Colkar & 4 & $\frac{t}{t}$ & & & & $\mathrm{v}$ & $x a b$, squangung \\
\hline 45 & FUSAI OART, SH & Colicar & $\frac{2}{5}$ & $\frac{11}{17}$ & & & & $\frac{v}{4}$ & $x a b$. squang \\
\hline 45 & ASOAWATI & Demoberat & $\frac{5}{1}$ & III & & & & $v$ & Kab. sijumiung \\
\hline 47 & Frena Nengagih, SE & Manura & $\frac{1}{1}$ & 114 & & & & $\mathrm{v}$ & Kos oharmastava \\
\hline 43 & $\begin{array}{l}\text { Suhendn } \\
\end{array}$ & Golkar & $\frac{1}{3}$ & III & & & & $\mathrm{v}$ & Kab. Solote \\
\hline 49 & 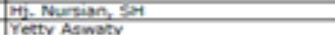 & Golar & $\frac{3}{6}$ & $\frac{t}{n}$ & & & & $\mathrm{v}$ & $\mathrm{xab}, \mathrm{sol} 2 \mathrm{k}$ \\
\hline
\end{tabular}


Tabel di atas menunjukan daftar caleg perempuan yang ikut serta bertarung pada pemilu 2014 lalu beserta dapil dan nomor urutnya. terlihat bahwa sebagian caleg perempuan mendapat nomor urut besar, hingga urutan nomor 9. untuk caleg yang mendapat nomor urut satu hanya berjumlah 10 orang dari 50 aleg perempuan yang lolos.

Lebih lanjut, penolakan dan larangan gerakan perempuan khususnya bundo kanduang terjun ke ranah pengambil keputusan juga berasal dari perangkat adat yang ada dikaum, salah satunya dari ninik mamak. Kondisi ini menyulitkan bundo kanduang dalam mendorong niat dan motivasi perempuan untuk mulai terjun ke wilayah publik. Usaha bundo kanduang dalam memotivasi perempuan untuk masuk ke ranah politik, sudah dulu terjegal di lingkungan privat perempuan itu sendiri. Organisasi bundo kanduang menilai adanya ketakutan segelintir kelompok yang khawatir jika peran perempuan sesuai adat minangkabau kembali lagi. Adanya kegamangan dari kaum laki laki untuk bersaing dan sejajar dengan perempuan. Hal ini membuat organisasi bundo kanduang tidak dapat bergerak bebas dalam menjalankan program-programnya dalam menghimpun atau mendorong perempuan untuk terjun kedalam lembaga legislatif.

Persoalan representasi perempuan di lembaga legislatif masih meninggalkan sederet pekerjaan rumah yang harus dijalani organiasi bundo kanduang, baik yang berasal dari dalam dirinya sendiri atau diluar tubuh organisasi bundo kanduang. Persoalan-persoalan yang telah dipaparkan tersebut merupakan benturan yang hingga kini masih dialami organisasi selaku kelompok kepentingan. Hingga saat ini belum ada solusi atau jalan keluar untuk mengatasi banyaknya tantangan keterwakilan perempuan di sumatera barat. gerakan dan usaha peguatan peran perempuan di lembaga legislatif Sumatera Barat yang diharapkan dari salah satu organisasi representasif perempuan minangkabau pun masih bersifat subtantif dan kurang optimal. 


\section{c. Dualisme Struktur Pemerintahan}

Penyeragaman bentuk pemerintahan terendah dalam bentuk desa pada masa orde baru, telah merusak sebagian struktur masyarakat terutama lembaga-lembaga tradisional yang dibentuk dan di hormati masyarakat. Pemaksaan penyeragaman ini memiliki dampak besar kepada masyarakat yang karakteristik masyarakatnya sangat berbeda dengan pola desa yang lebih cocok dengan masyarakat Jawa. Masuknya pola ke-jawa-an membawa unsur budaya patriarki di dalam sistem kemasyarakatan, sontak perlahan-lahan peran dan kedudukan perempuan bundo kanduangyang tadinya setara dengan kelompok laki-laki, mulai termajinalkan.

Segala kekuasaan, keputusan, ataupun pekerjaaan hanya boleh ditempati oleh kaum laki-laki. Kondisi ini berlangsung hingga berpuluh-puluh tahun lamanya.

Paska reformasi, otonomi daerah pun mulai digulirkan dan Sumatera Barat mulai mengaungkan bentuk sistem pemerintahan nagari. Realitanya, walaupun Sumatera Barat sudah kembali menerapkan sistem pemerintahan nagari namun dalam penyelenggaraanya belum kembali kepada karakter pemerintahan nagari sepenuhnya. Sosok yang tampil dalam penyelenggaraan pemerintah saat ini masih sama dengan sosok desa, yaitu dipisahkan anatara urusan administrasi pemerintahan dengan urusan adat istiadat. Penyelenggaraan pemerintah nagari hanya nama, belum bisa mengembalikan fungsi lembaga-lembaga adat sebagai penyelenggara pemerintahan. Keputusan kembali ke nagari hanya prosedural saja, tidak menghilangkan sifat kelembagaan yang dibentuk oleh rezim orde baru, khususnya pada lembaga bundo kanduang.

Dalam pelembagaan, organisasi bundo kanduang masih bersifat seremonial dan hanya melakukan penghimbauan. Gerakan bundo kanduang belum mengakar. Kekuasan bundo kanduang masih terbatas dan belum benar-benar bisa bergerak bebas sesuai dengan yang di 
amanatkan oleh adat minangkabau. Bundo kanduangselaku kelompok kepentingan sejauh ini peran yang mereka lakukan bisa dikatakan sebatas aktivitas sosial dan hanya menunggu perintah. Hadirnya Institusi Bundo kanduang, belum bisa memberikan banyak kontribusi ditengah-tengah hambatan yang menyebabkan kevakuman Institusi selama ini. Representasi formal Bundo kanduang pada era sekarang masih sangat jauh untuk menyentuh ranah representasi Bundo kanduang secara substansial sehingga membuat penguatan kualitas kepemimpinan dari Bundo kanduang sebagai mitra pemerintahan tidak berjalan sesuai dengan yang diharapkan.

Adanya faktor perbedaan struktur pemerintahan di Sumatera Barat, dimana masih terdapat sebagian daerah yang bersistem nagari dan sebagian lagi bersistem desa, menghantarkan penulis pada temuan bahwa organisasi bundo kanduang dalam menjalanan fungsinya belum benar-benar mampu menyentuh apa yang diamanatkan oleh perda nagari. Pada sebagian daerah yang masih menggunaan sistem desa, bundo kanduang tidak duduk dalam unsur pengambilan kebijaan. peranan bundo kanduang pada tataran ini hanya sebagai pelasana seremonial adat dan tida mempunyai peran politis. kondisi ini membuat organisasi tidak mempunyai wewenang dan bisa mendorong keikutsertaan perempuan di dalam urusan publik.

\section{KESIMPULAN}

Organisasi Bundo kanduang yang dahulunya hanya sebagai kelompok organisasi kemasyarakat yang fokus dalam pelestaian adat, kini mulai memainkan peran politisnya seiring dengan terbukanya kesempatan bundo kanduang untu ikut serta dalam pengambilan keputusan sesuai yang di amanatan dalam perda nagari. Organisasi bundo kanduang kemudian muncul sebagai sebuah gerakan kelompok perempuan yang bertujuan untuk memperkuat peranan kaum perempuan di sumatera barat sesuai dengan tatanan adat minangkabau, yang nantinya berdampak 
positif dalam mendorong kehadiran wakil-wakil perempuan di lembaga legislatif mulai dari nagari, Kabupaten/Kota Bahkan Provinsi.

Temuan-temuan dilapangan menunjukan bahwa gerakan politis yang dilakukan oleh bundo kanduang mampu memberikan dorongan modal sosial bagi perempuan untuk terjun dan masuk ke dalam lembaga pembuat kebijakan. Sesuai dengan Robert D. Putnam tentang modal sosial, organisasi bundo kanduang pun kemudian hadir sebagai modal sosidal dalam memfasiltatori program pemberdayaan perempuan yakni pemberdayaan mande soko. Organisasi bundo kanduang berupaya mengembalikan peran sentral mande soko dalam pengambilan kebijakan. Ketika Mande soko mulai berperan dan didengarkan, maka secara tidak langsung membuka akses bagi perempuan perempuan di nagari untuk menyampaikan aspirasi, melakukan lobi dan mempengaruhi kebijakan yang dihasilkan sehinggatidak merugikan prempuan, selain itu juga membuka kesempatan dan mengembalikan power politis perempuan minangkabau yang selama ini hilang. Mande soko diyakini sosok paling potensial dalam menggerakan basis -basis kaum perempuan.

Selanjutnya, sesuai dengan yang di ungkapkan Francis Fukuyama perihal modal sosial, organisasi bundo kanduang kemudian hadir sebagai modal sosial bagi para perempuan yang menjadi caleg pada pemilu 2014 lalu. . Dimana 3 orang aleg perempuan yang dudu di legislatif provinsi Sumatera Barat memperoleh kemenangan dengan mengandalkan bundo kanduang atau jaringan matrilineal.

Dalam mencapai tujuannya, organisasi bundo kanduang menggunakan sejumlah metode dan saluran politik. Organisasi Bundo kanduang merupakan sebuah kelompok yang bersifat formal, mempunyai fungsi-fungsi politik dan sosial. Mempunyai anggota yang khusus bertanggung jawab melakukan lobbying. Organisasi Bundo kanduang berpotensi besar dalam 
mempengaruhi kebijakan karena basis organisasinya sangat kuat dan bekerjasama dengan pemerintah atau birokrasi. Organisasi bundo kanduang dalam mencapai peningkatan representasi perempuan di lembaga legislatif juga melakukan sejumlah lobbying, perwakilan lansung, dan pendekatan dengan saluran formal dan institusional lainnya seperti partai politik, lembagalembaga adat, birokrasi pemerintah, Lsm dan tokoh-tokoh adat.

Namun dalam prakteknya, peningkatan peran perempuan tidak semudah membalikkan telapak tangan. Dalam menjalankan visi dan kebijakan organisasinya, Organisasi Bundo kanduang banyak menemui tantangan dan kendala sehingga tidak mencapai hasil maksimal. Penulis berhasil menguraikan apa saja yang menjadi hambatan-hambatan organisasi bundo kanduang dalam upaya mendorong representasi perempuan dilembaga legislatif, adapun hambatan tersebut berasal dari intern dan esktern bundo kanduang. Hambatan intern seperti masalah sumber daya organisasi yang meliputi ketersediaan anggaran yang minim, kurangnya pengetahuan politik para anggota Bundo kanduang, kemampuan lobbying yang kurang "mumpuni", dan masih kuatnya pengaruh warisan orde baru di dalam tubuh bundo kanduang sehingga paradigma berpikir masih berupa patriarki. Selain itu juga ditunjang dengan rendahnya motivasi organisasi bundo kanduang dalam mendukung para calon perempuan di pemilu akibat adanya bentuk ketidak percayaan kepada aleg-aleg perempuan lama yang telah duduk dilegislatif.

Sementara itu, faktor yang berasal dari luar adalah; persoalan budaya, agama hinggamasih belum terbukanya kesempatan perempuan untuk masuk ke ranah pengambil kebijakan dikarenakan struktur yang berlaku di masyarakat masih menerapkan sistem patriarki dan menjunjung tinggi prinsip agama islam, yang menempatkan pemimpin adalah laki laki. Paradigma berpikir ini bahkan tidak hanya terdapat pada kaum laki-laki, tapi juga disetujui oleh 
perempuan itu sendiri. Hal ini juga menyebabkan kurang mencuatnya isu-isu kebijakan terkait soal keterwakilan perempuan. isu menghadirkan perempuan di wilayah pembuat kebijakan bukan merupakan isu yang "urgent", hal ini juga di dukung dengan minimnya kelompok perempuan yang bergerak secara militan untuk melakukan sebuah gerakan perubahan atau desakan terkait keterwakilan perempuan di lembaga politik di Sumatera Barat.

Hambatan lainnya yang juga menjadi penyebab masih belum militannya gerakan yang dilakukan oleh organisasi bundo kanduang diakibatkan masih terdapatnya Dualisme sistem pemerintahan yang terjadi paska perubahan adat kembali ke nagari yang menimbulkan 'shock" atau kebingungan bagi institusi lokal di Sumatera Barat, sehingga institusi lokal tersebut tidak mampu mengaktulisasikan peran sosial dan politiknya dengan optimal. Ketiga,

Besarnya hambatan yang dihadapai oleh Bundo kanduang tersebut, membuat upaya penguatan peran perempuan dibidang keterwakilan menjadi tidak optimal. Pergerakan bundo kanduang saat ini masih seputar peran sosial dalam menyelenggarakan seremonial-seremonial adat. Gerakan Organisasi bundo kanduangdi Sumatera Barat terutama dalam mengembalikan peran kaum perempuan sesuai tatanan adat minangkabau secara umumnya dan mendorong keterwakilan perempuan di lembaga legislatf khususnya, masih membutuhkan sebuah gebrakan dan proses pembenahan diri. Diperlukan sebuah perubahan paradigma dan gerakan militan yang berasal dari perempuan Sumatera Barat sendiri untuk menemukan solusi dalam menghadirkan kembali perempuan minangkabau di ranah pengambilan keputusan ditengah dominasi patriarki yang terus mengakar meski Sumatera Barat bersimbol matrilineal. 


\section{DAFTAR PUSTAKA}

Almond, Gabriel A. \& Sidney Verba (1990).Budaya Politik: Tingkah Laku Politik dan Demokrasi di Lima Negara. Jakarta. Bumi Aksara.

Audrey Kahin. (2005). Dari Pemberontakan ke Integrasi Sumatera Barat dan Politik Indonesia. Jakarta. Yayasan Obor Indonesia.

Badan Pusat Statistik Provinsi Sumatera Barat. (2017). Statistik daerah provinsi Sumatera Barat tahun 2017.

Budiarjo, Miriam. (2008). Dasar-Dasar Ilmu Politik. Jakarta .Gramedia.

Bundo kanduang. (1983). Bunga Rampai Bundo kanduang. Padang. Bundo kanduang Sumatera Barat.

Bundo kanduang. (2015). Himpunan Ketetapan Musyawarah Besar VIII Organisasi Bundo kanduang Provinsi Sumatera Barat. Padang. Bundo kanduang Sumatera Barat.

Coleman, J.(1990). Foundations of Social Theory. Cambridge Mass. Harvard University Press.

Creswell, John W. (2002).Research Design, Qualitative \& Quantitative Approaches. Jakarta. KIK Press.

Chairiyah, Sri Zul. (2008). Nagari Minangkabau dan Desa Di Sumatera Barat : Dampak Penerapan UU No.5 tahun 1975 Tentang Sistem Pemerintahan Desa. Padang. Kaukus Perempuan Penyelenggara Pemilu Sumatera Barat.

Fakih, Mansour. (2004). Analisis Gender dan Tranformasi Sosial. Yogyakarta. Pustaka Pelajar.

Fatimah. (2012). GenderDalam Omunitas Masyarakat Minangkabau; Teori, Praktek dan Ruang Lingkup Kajian. 
Fukuyama, Francis. (2002). "Modal Sosial" dalam Kebangkitan Peran Budaya, Bagaimana Nilai-Nilai Membentuk Kemajuan Manusia, ed Lawrence E Harrison dan Samuel P Huntington, Jakarta: LP3ES.

Gaffar, Affan.(1999). Politik Indonesia: Transisi Menuju Demokrasi. Yogyakarta. PustakaPelajar.

Hakimi, Idrus DT. Rajo Penghulu. (1978). Buku Pegangan Bundo kanduang di Minangkabau. Bandung. CV Rosda.

Herlina, Lusi. (2003). Partisipasi Politik Perempuan Di Minangkabau (Suatu Pengantar). Jakarta. Ford Foundation.

Kato, Tsuyoshi. (1982). Matrinily and Migration : Envolving Minangkabau Tradition in Indonesia. Ithaca. Cornell University Press.

Koentjaraingrat, Prof. Dr. (2007). Manusia dan Kebudayaan di Indonesia, Jakarta. Penerbit Djambatan.

Moh Nazir.(1988). Metode Penelitian.. Jakarta. Ghalia Indonesia.

Moloeng, Lexy J. (2005). Metode Penelitian Kualitatif. Bandung. Remaja Rosdakarya.

Muiz, Hazwar. (2005). Perempuan Minangkabau Menurut Adat. Bukittinggi. Kristal Multimedia.

Nawawi, Hadari.(1987), Metodologi Penelitian Bidang Sosial. Yogyakarta. Gajah MadaUniversity Press.

Napitupulu, Paimim.(2007). Menakar Eurgensi Otonomi Daerah. Bandung. Alumni

Navis. A.A. (1984). Alam Takambang Jadi Guru;Adat Dan KebudayaanMinangkabau. Jakarta. Gravitti Perss. 
Philipus. Ng. \& Nurul Aini. (2011). Sosiologi dan Politik. Jakarta. Rajawali Press

Pusat Kajian Wanita dan Gender Universitas Indonesia. (2004). Hak Azasi Perempuan:Instrumen untuk mewujudkan keadilan Gender. Jakarta. Yayasan Obor Indonesia.

Sairin, Sjafri. (2002) . Perubahan Sosial Masyarakat Indonesia. Yogyakarta. Pustaka Pelajar.

Sanit, Arbi Drs. (1985) Perwakilan Politik Indonesia, Jakarta, CV Rajawali.

Sati Azwar Mu'is. Perempuan Minangkabau Menurut Adat. Kristal Multi Media.

Suseno, Nuri. (2013). Representasi Politik. Jakarta. Puskapol UI.

Tremblay, Manon (ed). (2008). Women and Legislative Representation : Electoral Systems, political parties and sex quotas. New York . Palgrave MacMillan.

Zuhro, R. Siti. (2003).Demokrasi lokal perubahan dan kesinambungan nilai-nillai budaya politik lokal. Jakarta. Gramedia Pustaka

\section{JURNAL}

Amaliatulwalidain, MA. (2015). Jurnal Pemerintahan dan Politik: Dinamika Representasi Peran Politik Bundo kanduang Dalam Sistem Pemerintahan Nagari Modern Dari Representasi Suntantif Menuju Representasi Formal Deskriptif. Vol.xx. No. Xx.

Aswirna, Prima \& Fahmi Reza.(2015).Man's Without Power : Gender Paradigm In West Sumatera. Article AICIS .

Fatimah, Siti. (2014). Gender Dalam Komunitas Masyarakat Minangkabau; Teori, Praktek, dan Ruang Lingkup Kajian. Jurnal Ilmiah Kajian Gender.Vol: 1. No: 1 
Idris, Nurwani. (2012). “Kedudukan Perempuan dan Aktualisasi Politik dalam Masyarakat Matrilinial Minangkabau” dalam Jurnal Masyarakat, Kebudayaandan Politik, Vol.25No.2/2012-02, Surabaya.

Idris, Nurwani. (2010). Perempuan Minangkabau dalam Politik, dalam Jurnal Humaniora, Volume 22 Nomor 2 Juni.

Idris, Nurwani. (2009). "Peran Politik Perempuan dalam Sistem Matrilineal di Minangkabau", dalam Jurnal Masyarakat, Kebudayaan dan Politik, Th.XXII. no.3Juli-September.

Irawati. (2010).Bundo kanduang Dan Tantangan Politik Dalam Badan Perwakilan Anak Nagari $(B P A N)$. Jurnal demokrasi vol IX. No.1.

Iskandar, Israr. (2014). Perempuan dan Mitos Demokrasi Minang. Analisis sejarah, volume 5 no.1. Labor Sejarah. Universitas andalas.

Jurnal Perempuan No 34. (2004).Politik dan Keterwakilan Perempuan, Yayasan Jurnal Perempuan. Jakarta.

Navis AA. (1984).Alam Takambang Jadi Guru: Adat dan Kebudayaan Minangkabau. Jakarta: Grafiti Pers.Navis AA (1999) Yang Berjalan

Pandiangan, Lidya Victorya. (2017). Perempuan Politisi Minangkabau Dalam Dunia Politik;Studi tentang Alasan Perempuan Memaknai Politik. Jurnal Politi Muda, Vol. 6, No.2 April-Juli 2017.

Paspirman, Ilia . Organisasi Bundo kanduang Di Kota Padang tahun 1974-2015.

Putri, Indah Adi. Strategi Politik Perempuan Caleg Sumatera Barat dalam Pemilu 2014. Journal Of Moral An Civic Education.

Putri, Indah Adi . (2017). Jaringan Kekerabatan Matrilineal Sebagai Modal Sosial Perempuan Caleg Dalam Pemilu 2014. Jurnal Antropologi: Isu-Isu Sosial Budaya. Desember 2017 Vol. 19 (2): 167-178.

Sismarni. Perubahan Peranan Bundo Anduang Dalam Kehidupan Masyaraat Minangabau Modern. Jurnal ilmiah kajian gender. 
Trinova, Zulvia \& Reski amalia dkk. (2017). Womans Subordination In Politic West Sumatera. Journalism and Mass Comunication Vol 7, No. 7.

Yunarti,Sri. ( 2017). Pemberdayaan Lembaga Bundo kanduang di Nagari Melalui Kebijakan Pembangunan Berbasis Gender. Kafaah :Journal of Gender Studies.

\section{SKRIPSI/TESIS/ DISERTASI}

Asmawita, Muharni . (2015) Efektivitas Lembaga Bundo kanduang Sebagai Kelompok Kepentingan Dalam Penyelenggaraan Pemerintahan Nagari Di Nagari Pariangan Kabupaten Tanah Datar. Diploma thesis, Universitas Andalas.

Jendrius. (2015).Decentralization, Direct Elections and The Return to Nagari: Women's Involvement and Leadership in West Sumatera, University of Malaya, Dissertation.

Simanjuntak, Mezbah. Pola Budaya Matrilineal Dalam Politik(Studi Kasus Keterwakilan Perempuan Di Dprd Sumatera Barat Tahun 2014). Skripsi. Universitas Sumatera Utara

\section{WAWANCARA}

Wawancara dengan Sitti Izzati pada tanggal 19 Maret 2018

Wawancara dengan Zusmiati pada tanggal 20 Maret 2018

Wawancara dengan Endarmy pada tanggal 20 Maret 2018

Wawancara dengan Marlina Suswati pada tanggal 20 maret 2018.

Wawancara dengan Armiati pada tanggal 20 maret 2018.

Wawancara dengan Elly Thiryanti, ketua DPRD Kota Padang pada tanggal 26 Maret 2018.

Wawancara dengan Ketua organisasi bundo kanduang sumatera barat pada tanggal 24 Maret 2018. 
Wawancara dengan Ketua pucuk pimpinan LKAMM pada tanggal 22 Maret 2018.

Wawancara dengan Komisioner KPU Sumatera Barat pada tanggal 23 Maret 2018.

Wawancara dengan pengurus Koalisi Perempuan Indonesia Sumatera Barat, Fitriani pada tanggal 20 Maret 2018.

Wawancara dengan Lembaga Nurani Perempuan pada tanggal 26 Maret 2018

Wawancara dengan Kepala Dinas Pemberdayaan Perempuan dan Anak Provinsi Sumatera Barat pada tanggal 24 Maret 2018.

Wawancara dengan Kabid Kualitas Hidup Perempuan Dinas PPA Sumatera Barat pada tanggal 23 Maret 2018.

Wawancara dengan kepala sekretariat partai Golkar pada tanggal 21 Maret 2018

\section{WEBSITE}

www.kpu-sumbar.co.id

www. pemprovsumbar.go.id

www.bps-sumbar.go.id

www.padangmedia.com/ P.R Raudha Thaib. Menyusun Strategi Pemberdayaan Perempuan Di Nagari-Nagari . 